\title{
Comparing the cloud vertical structure derived from several methods based on measured atmospheric profiles and active surface measurements
}

\section{Costa-Surós ${ }^{1}$, J. Calbó ${ }^{1}$, J. A. González ${ }^{1}$, and C. N. Long ${ }^{2}$}

${ }^{1}$ Group of Environmental Physics, Physics Department, University of Girona, Girona, Spain ${ }^{2}$ Pacific Northwest National Laboratory, Atmospheric Measurements Laboratory, Richland, Washington, USA

Received: 3 May 2013 - Accepted: 11 May 2013 - Published: 3 June 2013

Correspondence to: M. Costa-Surós (montse.costa@udg.edu)

Published by Copernicus Publications on behalf of the European Geosciences Union.

\section{Comparing the cloud vertical structure derived from several methods \\ M. Costa-Surós et al.}

\section{Title Page}

Abstract

Conclusions

Tables

14

4

Back 


\section{Abstract}

The cloud vertical distribution and especially the cloud base height, which is linked to cloud type, is an important characteristic in order to describe the impact of clouds in a changing climate. In this work several methods to estimate the cloud vertical structure 5 (CVS) based on atmospheric sounding profiles are compared, considering number and position of cloud layers, with a ground based system which is taken as a reference: the Active Remote Sensing of Clouds (ARSCL). All methods establish some conditions on the relative humidity, and differ on the use of other variables, the thresholds applied, or the vertical resolution of the profile. In this study these methods are applied to 125 radiosonde profiles acquired at the ARM Southern Great Plains site during all seasons of year 2009 and endorsed by GOES images, to confirm that the cloudiness conditions are homogeneous enough across their trajectory. The overall agreement for the methods ranges between $44-88 \%$; four methods produce total agreements around $85 \%$. Further tests and improvements are applied on one of these methods. In addition, we be useful in atmospheric modeling. The total agreement, even when using low resolution profiles, can be improved up to $91 \%$ if the thresholds for a moist layer to become a cloud layer are modified to minimize false negatives with the current data set, thus improving overall agreement.

\section{Introduction}

Clouds are a key factor driving the climate. The complexity of the processes involved, the vast amount of information needed, including spatial distribution, and the uncertainty associated with the available data, all add difficulties to determining how clouds contribute to climate change (e.g., Heintzenberg and Charlson, 2009). There is, in consequence, a general need for improvement of automatic cloud observation and continuous cloud description.

\section{Comparing the cloud vertical structure \\ derived from several methods \\ M. Costa-Surós et al.}

Title Page

Abstract Introduction

Conclusions

References

Tables

Figures

14

$\Delta \mathbf{I}$

4

Back

Close

Full Screen / Esc

Printer-friendly Version

Interactive Discussion 
Specifically, knowledge about cloud type is very important because the overall impact of clouds on the Earth energy budget is difficult to estimate as it involves two opposite effects depending on cloud type (Naud et al., 2003). Low, highly reflective clouds tend to cool the surface, whereas high, semitransparent clouds tend to warm it. In addition, the cloud vertical structure (CVS) affects the atmospheric circulation directly by modifying the radiative cooling profile and the atmospheric static stability. The effects of cloud vertical structure on atmospheric circulation have been described through the use of atmospheric models by many authors, such as Wang and Rossow (1998). Moreover, Crewell et al. (2004) underlined the importance of clouds in multiple scattering and absorption of sunlight, processes that have a significant impact on the diabatic heating in the atmosphere. These complex phenomena are not yet fully understood and are subject to large uncertainties.

The assumed or computed vertical structure of cloud occurrence in general circulation models (GCMs) is one of the main reasons why the different models predict a wide range of future climates. For example, most GCMs underestimate the cloud cover while only a few overestimate it (Xi et al., 2010). Therefore, to improve the understanding of cloud-related processes, and then to increase the predictive capabilities of large-scale models (including global circulation models), better and more accurate observations of both global cloud amount and in particular of the vertical distributions of clouds are needed. The present work is a contribution towards addressing this need.

Observations and measurements are fundamental to acquire insight regarding cloud processes. These can be performed from the ground or from satellite. In both cases, the problem of overlapping cloud layers that hide each other is noticeable. Surface observers can see most of the low clouds with or without higher clouds above them, while satellites can observe most of the high clouds with or without lower clouds underneath. These limitations have hindered the development of reliable quantitative information about cloud overlap and, in general, about the vertical distributions of cloud fractions and cloud occurrence. However, ground-based and space-borne cloud radars can partially overcome this issue.
ACPD

13, 14405-14445, 2013

\section{Comparing the cloud vertical structure \\ derived from several methods \\ M. Costa-Surós et al.}

Title Page

Abstract Introduction

Conclusions

Tables References

Figures

14 $\Delta \mathbf{I}$

4

Back

Close

Printer-friendly Version

Interactive Discussion 
Ground-based instruments such as lidar, cloud radar and ceilometers are usually applied to observe and describe the CVS. They can provide cloud measurements with high accuracy and continuous temporal coverage, however radar and lidar are deployed at few locations around the world and their application is limited. Ceilometers 5 are commonly located at airports but they are used only for operational purposes, not for research, and have a limited range that does not cover the total troposphere. Ceilometers are very efficient at detecting clouds and can locate the bottom of cloud layers precisely, but cannot usually detect the cloud top due to attenuation of the beam within the cloud. On the other hand, the vertically pointing cloud radar is able to de10 tect the cloud top, although signal artifacts can cause difficulties during precipitation (Nowak et al., 2008). In this context, the Atmospheric Radiation Measurement (ARM) Program developed the Active Remote Sensing of Clouds (ARSCL) product that combines data from several ground-based instruments to produce a time series of vertical distributions of cloud hydrometeors over the ARM sites (Clothiaux et al., 2000). Jin et al. (2007) recalled the importance of obtaining the cloud vertical structure by using ground-based active instruments because, in the past, satellite-based cloud datasets retrieved from passive remote sensing techniques were unable to provide the CVS.

Passive satellite sensors have the advantage of providing global coverage of cloud amounts and top heights, although their retrieval accuracy suffers from various limitations. More recently, new instruments onboard satellites are providing details about the cloud vertical structure. In particular, active sensors such as the Cloud Profiling Radar (CPR) on CloudSat and the Cloud-Aerosol Lidar with Orthogonal Polarization (CALIOP) aboard CALIPSO (Cloud-Aerosol Lidar and Infrared Pathfinder Satellite Observation) satellites are achieving notable results regarding the addition of a vertical dimension to traditional satellite images. However, because the repeat time of these polar orbiting satellites for any particular location is very large, the time resolution of such observations is low (L'Ecuyer and Jiang, 2010; Qian et al., 2012).

An indirect way to perform estimations of CVS is by using atmospheric thermodynamic profiles as measured by radiosondes. Radiosondes can penetrate atmospheric

\section{ACPD}

13, 14405-14445, 2013

\section{Comparing the cloud vertical structure \\ derived from several methods \\ M. Costa-Surós et al.}

Title Page

Abstract Introduction

Conclusions

Tables References

Figures

14 $\Delta \mathbf{I}$

4

Back

Close

Printer-friendly Version

Interactive Discussion 
(and cloud) layers to provide in situ data. The vertical distributions of temperature, relative humidity and pressure measured by radiosondes are fundamental to the study of atmospheric thermodynamic and dynamic processes (Zhang et al., 2010). Actually, radiosoundings were probably the best method to obtain the CVS from the ground 5 before the ARSCL development; currently they are the only solution to get a groundbased, global knowledge of CVS thanks to the network of radiosonde launching stations (around 800 worldwide). Moreover, radiosoundings are used as a reference for other upper air detection techniques (Wang et al., 2000; Eresmaa et al., 2006; Zhang et al., 2010).

10 There are several methods available in the literature to determine the CVS from radiosonde data. In this study, six of these methods are applied to a number of atmospheric profiles obtained at the ARM Southern Great Plains (SGP) site, and their results compared among them. All methods establish some conditions on the relative humidity (or closely related magnitudes, such as dew point depression) or its vertical variation. Some of them add conditions related to cloud layers depth or regarding the vertical resolution required for the radiosonde profile. The methods examined here are those by Poore et al. (1995); Wang and Rossow (1995); Chernykh and Eskridge (1996); Dimitrieva-Arrago and Shatunova (1999); Minnis et al. (2005) and Zhang et al. (2010). These six methods are described in Sect. 2.

Some authors have already performed comparison studies, although to our knowledge, none of these previous works has compared as many methods. For example, Naud et al. (2003) compared the methods by Wang and Rossow (1995) and Chernykh and Eskridge (1996), using data (November 1996-October 2000) from surface-based active sensors placed at the ARM SGP site. In the same paper, the authors checked the effect of applying different thresholds on the relative humidity for the first method and modified the second method by making it dependent on the cloud cover and altitude. They concluded that Wang and Rossow (1995) method tends to classify moist cloudless layers as cloudy (especially at lower altitudes), furthermore, they suggested that the two methods tend to report cloud top heights that are higher than the corre-

\section{ACPD}

13, 14405-14445, 2013

\section{Comparing the cloud vertical structure \\ derived from several methods \\ M. Costa-Surós et al.}

Title Page

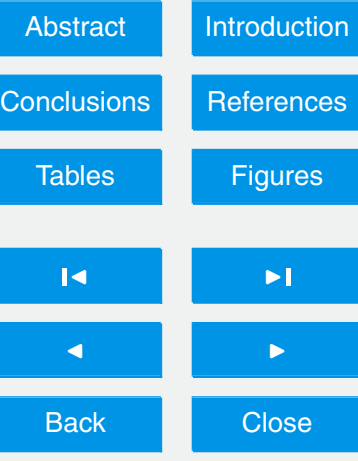

Full Screen / Esc

Printer-friendly Version

Interactive Discussion 
sponding heights from radar observations. In a more recent comparison work, Zhang et al. (2012) conducted a campaign in China where a cryogenic frostpoint hygrometer, a Vaisala RS80 radiosonde, and a GTS1 radiosonde were deployed. They compared again the methods by Wand and Rossow (1995) and Chernykh and Eskridge (1996)

5 and adapted them to the specific behavior of every radiosonde instruments that they used. Overall, results from these earlier comparison studies have clearly demonstrated the value of radiosonde data for determining cloud vertical structure. However, they have also shown that different methods produce slightly different results, and that the cloud vertical structure derived from radiosondes data diverges sometimes from active 10 sensor observations. These latter differences could be partly attributed to comparing retrievals from ground-based instruments, which have just a vertical view of the sky above, against CVS derived from radiosondes, which suffer a horizontal displacement due to the wind while they are ascending.

This study presents a comparison of the CVS obtained from methods based on ra15 diosonde profiles with estimations produced by ground-based active instruments (that is, the ARSCL cloud base and top heights) in order to find the best approximation to the real CVS and to reveal the strengths and weaknesses of the methods used. Also Geostationary Operational Environmental Satellites (GOES) images are used to face the problem of the radiosonde (RS) horizontal drift. Secondly, some improvements are suggested and the effect of lowering the vertical resolution of profiles is analyzed (to potentially make these methods suitable for GCMs and weather forecast models).

\section{Data and methodology}

\subsection{ARSCL, radiosondes, satellite images and sky images}

Data used in this study come from the Department of Energy (DOE) Atmospheric Radiation Measurement (ARM) Program, specifically from the Southern Great Plains site (SGP, $36^{\circ} 36^{\prime} 18.0^{\prime \prime} \mathrm{N}, 97^{\circ} 29^{\prime} 6.0^{\prime \prime} \mathrm{W}, 320$ ma.s.I., OK, US). Data from 165 radioson-

\section{ACPD}

13, 14405-14445, 2013

\section{Comparing the cloud vertical structure \\ derived from several methods \\ M. Costa-Surós et al.}

Title Page

Abstract Introduction

Conclusions

References

Tables

Figures

14

$\Delta \mathbf{I}$

4

Back

Close

Full Screen / Esc

Printer-friendly Version

Interactive Discussion

\section{lose}


des (corresponding to 44 days), which have been randomly selected and intended to be representative of all seasons of year 2009, have been studied. In general, four times per day are used, corresponding to the four radiosonde launches at this site. The schedule for the routine launch operations is $23: 30,05: 30,11: 30$, and 17:30 UTC 5 which corresponds to 6:30 p.m., 12:30 a.m., 6:30 a.m., and 12:30 p.m. Central Daylight Time (CDT).

Cloud base and top heights $(\mathrm{CBH}$ and $\mathrm{CTH})$ are the main variables used in the present study; they are taken from the Active Remote Sensing of Clouds (ARSCL) product. ARSCL is a value-added product that combines data from active remote sensors: millimeter cloud radars (MMCR), laser ceilometers (VCEIL), and micropulse lidars (MPL), and provides a time series (with $10 \mathrm{~s}$ resolution) of vertical distributions of cloud hydrometeors over the ARM sites (Clothiaux et al., 2000). Both MPL and VCEIL cannot penetrate thick low-level clouds to detect any more layers of clouds aloft. However, they can detect clouds that are visible from the ground within the observation ranges, though

the MPL does sometimes label as layers with cloud optical thickness less than is typically used as a limit for human and sky imager observations. The greatest strength of the cloud radar is its ability to penetrate clouds and reveal multiple-layer structures but may miss some thin clouds composed of small hydrometeors. Yet the detection of cloud base heights from radar is often affected by the presence of large precipitation particles, as well as insects and bits of vegetation. If such particles are suspended in the atmospheric boundary layer, this may be mistakenly regarded as stratus clouds (Clothiaux et al., 2000). The properties of the three instruments are specified in Table 1. In summary, cloud radar-lidar systems can provide more accurate cloud vertical distributions and compensate for most of the shortcomings in cloud vertical distributions from surface observers and even from satellite imagery (Xi et al., 2010). However, ARSCL product has the limitation of providing only a "pencil" beam, because the instruments only view a small column of the atmosphere above them.

The main product from ARSCL is the Cloud Base Best Estimate (CBBE) which is determined from MPL and VCEIL measurements only (no MMCR data are used). If the

\section{ACPD}

13, 14405-14445, 2013

Comparing the cloud vertical structure

derived from several methods

M. Costa-Surós et al.

Title Page

Abstract Introduction

Conclusions

Tables References

Figures

14 $\Delta \mathbf{I}$

4

Back

Close

Full Screen / Esc

Printer-friendly Version

Interactive Discussion 
ceilometer first cloud base is between 0 and $3000 \mathrm{~m}$, the ceilometer value is used; if the ceilometer cloud base is above $3000 \mathrm{~m}$, but within $600 \mathrm{~m}$ of the MPL first cloud base, the ceilometer value is used. Otherwise, MPL first cloud base is used. The difference between cloud height determination algorithms using VCEIL and MPL is that MPL uses

5 a threshold variation to identify the cloud bottom, while ceilometers use a calculated vertical visibility threshold of $100 \mathrm{~m}$. This means that the ceilometer will not classify thin cloud regions that MPL would identify and usually give a slightly higher cloud bottom height (Morris, 2012). Besides the CBBE, ARSCL provides bases and tops for up to 10 cloud layers, based on MMCR and MPL data. The best situation is when the cloud 10 top is determined by MMCR; if this instrument is not available, the cloud top is derived from MPL, or if the MPL beam is attenuated by the lower cloud then noted as not being retrieved.

Radiosondes measure local conditions when they ascent through the atmosphere; obviously, they also produce data when they cross cloud layers. Vertical distributions of temperature, relative humidity $(\mathrm{RH})$ and pressure measured by radiosondes are fundamental values to obtain the cloud vertical structure by applying the six methods compared in this study. The sonde model used at the SGP Central Facility in the year 2009 was the RS92-SGP manufactured by Vaisala. The used profiles have a high vertical resolution (less than $10 \mathrm{~m}$ ) as result of considering measurements every $2 \mathrm{~s}$ and an ascent rates in the range $2.5-5.5 \mathrm{~m} \mathrm{~s}^{-1}$. Besides pressure, temperature and relative humidity, altitude and dew point temperature (among others) are provided in the radiosounding files.

The radiosonde horizontal displacement, due to the drift produced by the wind, must be taken into account because it could add some difficulty when comparing the clouds detected by the RS methods with the ARSCL "pencil view". In order to address this issue, we have first represented in Fig. 1 the horizontal displacement depending on the vertical position as a box-plot diagram for the whole RS dataset. At maximum level of low clouds base $(2 \mathrm{~km})$, displacements are between 0.4 and $11 \mathrm{~km}$. At $6 \mathrm{~km}$ height, the boundary between middle and high clouds, displacements are between 1.6 and

\section{ACPD}

13, 14405-14445, 2013

\section{Comparing the cloud vertical structure \\ derived from several methods \\ M. Costa-Surós et al.}

Title Page

Abstract Introduction

Conclusions

Tables

References

Figures

14

-1

4

Back

Close

Full Screen / Esc

Printer-friendly Version

Interactive Discussion 
$47 \mathrm{~km}$. At $15 \mathrm{~km}$ height, the horizontal distance to the launch point ranges from 14 to $210 \mathrm{~km}$. The median distance steadily grows with height, reaching $79 \mathrm{~km}$ at $15 \mathrm{~km}$. As a conclusion, the horizontal drift of the RS can be an issue when comparing with fixed instrumentation, since half of the soundings go farther than $79 \mathrm{~km}$. The horizontal 5 positions of the RS when they reach $15 \mathrm{~km}$ height are represented in the inset of Fig. 1 . The RS drifts are always towards the East, due to the prevalence of the Westerlies at middle latitudes.

Considering this large horizontal distances travelled by the RS, it may well happen that clouds crossed by RS differ from clouds over the ARSCL site. Therefore, to select 10 those RS which trajectory goes through a homogeneous region of the atmosphere, GOES images have been used to evaluate the cloudiness (or the absence of it) in the area. Geostationary Operational Environmental Satellites (GOES), operated by the United States National Environmental Satellite, Data and Information Service (NESDIS) and used by the National Weather Service (NWS), carry a five-channel (one vis15 ible, four infrared) imaging radiometer system, designed to sense radiant and solar reflected energy from sampled areas of the Earth. Here, sequences of GOES images every 15 min have been analyzed corresponding to periods between the RS launches and bursts. An area of $300 \times 500 \mathrm{~km}^{2}$ eastwards of the SGP site has been inspected. Both visible channel (band 1) images, when available, and infrared atmospheric window channel (band 4) images have been used. Visible images allow distinguishing the low clouds due to its high reflectance while infrared images are more useful to detect high clouds because of their low temperature. In addition, we check that the cloudiness derived from GOES images is compatible with what ARSCL produces over SGP. With these two conditions, some RS have been rejected from the original RS database, so still well distributed seasonally: winter $26 \%$, spring $23 \%$, summer $21 \%$, and autumn $30 \%$. The entire procedure will be further explained by means of examples included in Sect. 3.1.

\section{ACPD}

$13,14405-14445,2013$

\section{Comparing the cloud vertical structure \\ derived from several methods \\ M. Costa-Surós et al.}

Title Page

Abstract Introduction

Conclusions

References

Tables

Figures

14

$\Delta \mathbf{I}$

4

Back

Close

Full Screen / Esc

Printer-friendly Version

Interactive Discussion 
Finally, a total sky imager (TSI-660 by Yankee Environmental Systems) provides time series of hemispheric sky images during daylight hours and retrievals of fractional sky cover for periods when the solar elevation is greater than $10^{\circ}$. These images add some useful information when analyzing and interpreting results of ARSCL and radiosonde 5 cloud vertical structure.

\subsection{Cloud Vertical Structure estimative methods}

As already commented, we have considered six methods to determine CVS from radiosondes. However, as this work is based on techniques that have been developed and published earlier, we will not extensively describe their development; instead, Table 2 contains a summary of their main characteristics and a short description is given below.

Poore et al. (1995) developed a methodology (hereinafter PWR95) with the aim to build a cloud climatology combining $14 \mathrm{yr}$ (1975-1988) of surface and upper-air observations (radiosoundings) at 63 sites in the Northern Hemisphere $\left(0^{\circ}\right.$ to $80^{\circ} \mathrm{N} ; 34$ continental sites, 14 coastal sites, and 15 on islands). The main idea of PWR95 method is to estimate the cloud base and top heights from temperature-dependent dew point depression thresholds. In the PWR95 method, the radiosounding processing is limited to temperatures above $-40^{\circ} \mathrm{C}$ or at a maximum of 10668 ma.g.l. The radiosounding is linearly interpolated every $76 \mathrm{~m}$ and the dewpoint depression $\left(\Delta T_{\mathrm{d}}\right)$ is calculated as

$\Delta T_{\mathrm{d}}=T-T_{\text {dew }}$

According with PWR95, a given atmospheric level has a cloud if

$\Delta T_{\mathrm{d}}<1.7^{\circ} \mathrm{C}$ at $T>0^{\circ} \mathrm{C}$

$\Delta T_{\mathrm{d}}<3.4^{\circ} \mathrm{C}$ at $0>T>-20^{\circ} \mathrm{C}$
ACPD

$13,14405-14445,2013$

Comparing the cloud vertical structure

derived from several methods

M. Costa-Surós et al.

Title Page

Abstract

Introduction

Conclusions

References

Tables

Figures

14

$\Delta \mathbf{I}$

4

Back

Close

Full Screen / Esc

Printer-friendly Version

Interactive Discussion 
which, in terms of $\mathrm{RH}$, is approximately equivalent to

$\mathrm{RH}>91.5 \%$ at $T>0{ }^{\circ} \mathrm{C}$

$13,14405-14445,2013$

$\mathrm{RH}>83 \%$ at $0>T>-20^{\circ} \mathrm{C}$

$\mathrm{RH}>74 \%$ at $T<-20^{\circ} \mathrm{C}$

Finally, some additional conditions are applied: specifically, a minimum cloud-layer thickness of $30.5 \mathrm{~m}$ (for low clouds, $\mathrm{CBH}<1981 \mathrm{~m}$ ) and $61 \mathrm{~m}$ (for middle and high clouds); cloud layers that extend to the top of the RS profile are discarded because they have indeterminate top heights.

$10 \quad$ Wang and Rossow (1995) (WR95 method) slightly modified the PWR95 method. First, for levels with temperatures lower than $0{ }^{\circ} \mathrm{C}, \mathrm{RH}$ is computed with respect to ice instead of liquid water, which allows the use of a single threshold $\mathrm{RH}$ at all levels. This single threshold is set to $84 \%$ to identify a moist level; within a moist layer (i.e. several successive moist levels), the maximum $\mathrm{RH}$ must be greater than $87 \%$ to be considered 15 as a cloud layer. In addition, if $\mathrm{RH}$ at the base (top) of the moist layer is lower than $87 \%$, a $\mathrm{RH}$ jump exceeding $3 \%$ must exist from the underlying (above) level. All cloud layers independently of their thickness, including single-level clouds, are retained in WR95. Another improvement is that cloud layers ending at the maximum observation altitude, which were discarded in PWR95, are kept in WR95. Finally, the minimum value of a cloud base height is set at 500 ma.g.l.

The WR95 method was tested at 30 ocean sites by comparing with cloud properties derived from other independent data sources (visual observations and ISCCP data). The radiosonde data covered from 1946 to 1991; the sites were selected to supplement the poor ocean coverage of PWR95 dataset. The radiosounding dataset used by WR95 did not have as high resolution as the radiosounding data from SGP that are used in the present study. For this reason, when applying WR95 method, we have first reduced the radiosonde resolution at approximately the same resolution of the original work (that is, mandatory pressure levels, significant points, and maximum distance between

\section{Comparing the cloud vertical structure \\ derived from several methods \\ M. Costa-Surós et al.}

Title Page 
levels fixed at $200 \mathrm{~m}$ ). The method for resolution reduction is based on Chernykh and Eskridge (1996), see immediately below.

The CE96 method (Chernykh and Eskridge, 1996), based on previous methods developed in the former Soviet Union, was evaluated using data from several United

5 States radiosonde stations within different climates. Evaluation data was selected to include only situations where the observer could only see one cloud layer. Consequently, the evaluation is biased towards stratified cloud conditions. A few years later, Chernykh and Aldukhov (2004) further developed this method and applied it to one month of data from the Surface Heat Budget of the Arctic Ocean (SHEBA) experiment, 10 along with satellite observations made during Phase II of the FIRE Arctic Cloud Experiment and sounding data from the National Center for Atmospheric Research (NCAR) C-130Q research aircraft.

The first step in the CE96 method is to build a new vertical profile with lower resolution. The new, coarse profile must include these levels (with the corresponding values obtained by interpolation between the original measured values):

- Mandatory pressure levels (where $P=1000,925,850,700,500,400,300,250,200$, $150,100,70,50,30,20,10 \mathrm{hPa})$.

- Significant levels, to avoid differences greater than $0.5^{\circ} \mathrm{C}$ (air temperature) and $2.5 \%$ (relative humidity) between two consecutive levels.

- Additional levels to obtain a maximum distance of $200 \mathrm{~m}$ between them.

In fact, Chernykh and Aldukhov (2004) used this technique to reduce the radiosonde data resolution and tested different values (from $100 \mathrm{~m}$ to $700 \mathrm{~m}$ ) for the maximum distance between levels; based on their conclusions we have used a value of $200 \mathrm{~m}$ in the present work.

25 According to the CE96 method, the necessary condition for the existence of clouds in a given atmospheric level is that the second derivatives with respect to height $(z)$ of

Comparing the cloud vertical structure derived from several methods

M. Costa-Surós et al.

Title Page

Abstract Introduction

Conclusions

Tables References

Figures

14 -1

4

Back

Close

Full Screen / Esc

Printer-friendly Version

Interactive Discussion
$>$

nteractive Discussion 
temperature and relative humidity be positive and negative respectively:

$T^{\prime \prime}(z) \geq 0$ and $\mathrm{RH}^{\prime \prime}(z) \leq 0$

To calculate the second derivative, the temperature and relative humidity profiles are first approximated by cubic splines; in this way the second derivatives can be continu5 ously estimated over the entire vertical profile as linear functions over each segment.

Then, when the previous conditions are met in a given level, the Arabey diagram (Chernykh and Eskridge, 1996) is applied to evaluate the cloud cover in it. If cloud cover is determined to be less than $20 \%$, that level will not be considered as cloudy. In addition, for a succession of levels accomplishing both criteria to form a cloud layer, they must total a minimum thickness of $100 \mathrm{~m}$.

Chernykh and Eskridge (1996) argued that this methodology makes physical sense because in a region of the atmosphere containing clouds, one expects higher relative humidity than in the layer above and below the cloud layer. Hence, a local maximum $\left(\mathrm{RH}^{\prime \prime}(z) \leq 0\right)$ must be reached. They also commented that clouds ordinarily have a more defined top than base and nearly always lie under a temperature inversion (so $T^{\prime \prime}(z) \geq 0$ at the cloud top). Condensation of water vapor and its accompanying release of latent heat make it reasonable for temperature to stop decreasing with height or to increase with height near the base of a cloud (hence, a local minimum, i.e. $T^{\prime \prime}(z) \geq 0$ is also expected at the cloud base).

20 The basis of the DS99 method (Dimitrieva-Arrago and Shatunova, 1999; L. Dimitrieva, personal communication, 2012) is the vertical distribution of dew point depression $\left(\Delta T_{\mathrm{d}}\right)$ in the atmosphere, as in the PWR95 method. Characteristic values of dew point depression in clouds are known from analysis of the great amount of aircraft data (mostly for stratiform clouds) conducted by specialists of the Hydrometeorological 25 Scientific Research Center of Russia. Thus, Dimitrieva-Arrago and Koloskova (1969) carried out a comparison of cloud vertical structure (location of cloud boundaries and cloud thickness) calculated using characteristic values of $\Delta T_{\mathrm{d}}$ with real cloud distributions derived from aircraft data. From this previous study, the method is quite simple.

Comparing the cloud vertical structure derived from several methods

M. Costa-Surós et al.

Title Page

Abstract Introduction

Conclusions

References

Tables

Figures

14

-1

4

Back

Close

Full Screen / Esc

Printer-friendly Version

Interactive Discussion 
First, the dew point depression must be calculated at every radiosonde level. Then, three pressure-dependent dew point depression thresholds are applied to find the cloud layers:

$\Delta T_{\mathrm{d}}<1.5^{\circ} \mathrm{C}$ at $1000 \mathrm{hPa}>P>800 \mathrm{hPa}$

$5 \Delta T_{\mathrm{d}}<2.5^{\circ} \mathrm{C}$ at $800 \mathrm{hPa}>P>550 \mathrm{hPa}$

$\Delta T_{\mathrm{d}}<5^{\circ} \mathrm{C}$ at $550 \mathrm{hPa}>P>300 \mathrm{hPa}$

Assuming the typical temperature found in the corresponding pressure range, $\Delta T_{\mathrm{d}}$ thresholds can be expressed as $\mathrm{RH}$ thresholds:

$$
\begin{aligned}
& \mathrm{RH}>92.5 \% \text { at } 1000 \mathrm{hPa}>P>800 \mathrm{hPa}\left(\text { at } 15^{\circ} \mathrm{C}\right) \\
& \mathrm{RH}>87.5 \% \text { at } 800 \mathrm{hPa}>P>550 \mathrm{hPa}\left(\text { at } 0{ }^{\circ} \mathrm{C}\right) \\
& \mathrm{RH}>75 \% \text { at } 550 \mathrm{hPa}>P>300 \mathrm{hPa}\left(\text { at }-20^{\circ} \mathrm{C}\right)
\end{aligned}
$$

Minnis et al. (2005, MNS05 hereafter) provided a new cloud detection method derived 15 from high temporal resolution ARSCL data, balloon-borne soundings, and satellite retrievals over the ARM SGP Central Facility between 1 March 2000 and 28 February 2001. MNS05 is an empirical parameterization that calculates the probability of occurrence of a cloud layer using $\mathrm{RH}$ and air temperature from radiosondes. First, $\mathrm{RH}$ values must be converted to $\mathrm{RH}$ with respect to ice when temperature is less than $-20^{\circ} \mathrm{C}$; on the other hand, the profile has to be interpolated every $25 \mathrm{hPa}$ up to the height of $100 \mathrm{hPa}$. Then an expression to estimate the cloud probability $\left(P_{\text {cld }}\right)$ as a function of temperature and relative humidity is applied; in this formula, relative humidity is given the maximum influence since it is the most important factor for cloud formation. Finally, a cloud layer is set wherever $P_{\text {cld }} \geq 67 \%$. Jin et al. (2007) slightly modified this method for its application to Arctic conditions (i.e. colder and less polluted). Minnis et al. (2005) developed their method to compare it with the Rapid Update Cycle (RUC) $40 \mathrm{~km}$ resolution model results (so a different goal than the other methods presented in this section, i.e. to create cloud climatologies). However, we have adapted and applied

Comparing the cloud vertical structure derived from several methods

M. Costa-Surós et al.

Title Page

Abstract Introduction

Conclusions References

Tables

Figures

14

$\Delta \mathbf{I}$

4

Back

Close

Full Screen / Esc

Printer-friendly Version

Interactive Discussion 
it in the present study given that the method produces what we would like to analyze: the CVS from vertical thermodynamic profiles.

Zhang et al. (2010, ZHA10 hereafter) developed their methodology on the basis of data obtained during a campaign in Shouxian (China) from 14 May to 28 December

5 2008, where the ARM Mobile Facility (AMF) was deployed. Radiosonde data were used to analyze cloud vertical structure by taking advantage of the first direct measurements of cloud vertical layers from the $95 \mathrm{GHz}$ radar. ZHA10 method is clearly an improvement of WR95 method. Instead of single WR95 threshold, ZHA10 is based on altitude dependent thresholds without the requirement of the $3 \% \mathrm{RH}$ jump at the cloud 10 base and top. Threshold values depending on height are shown in Table 3. According to their own results, Zhang et al. (2010) concluded that cloud layers retrieved using the ZHA10 method agree well with the surface active remote sensing observations (cloud radar, MPL, ceilometer) of cloud vertical distributions.

As a first step, the $\mathrm{RH}$ with respect to liquid water is converted to $\mathrm{RH}$ with respect to 15 ice when the temperature is below $0{ }^{\circ} \mathrm{C}$. Then, moist layers are identified by applying four conditions: (a) the base of the lowest moist layer is determined as the level where $\mathrm{RH}$ exceeds the minimum $\mathrm{RH}$ threshold (min- $\mathrm{RH}$ ) corresponding to this level, (b) above the base of the moist layer, contiguous levels with $\mathrm{RH}$ over the corresponding min- $\mathrm{RH}$ are treated as the same layer, (c) the top of the moist layer is identified where $\mathrm{RH}$ decreases below the corresponding $\mathrm{min}-\mathrm{RH}$, and (d) moist layers with bases lower than $120 \mathrm{~m}$ and thicknesses less than $400 \mathrm{~m}$ are discarded. Subsequently, cloud layers are defined through four additional steps: (a) a moist layer is classified as a cloud layer if the maximum $\mathrm{RH}$ within this layer is greater than the corresponding maximum $\mathrm{RH}(\max -\mathrm{RH})$ at the base of this moist layer, (b) the base of cloud layers is set to 280 ma.g.I., and cloud layers are discarded if their tops are lower than $280 \mathrm{~m}$, (c) two contiguous layers are considered as a single layer cloud if the distance between these two layers is less than $300 \mathrm{~m}$ or the minimum $\mathrm{RH}$ within this distance is greater than the maximum inter- $\mathrm{RH}$ value, and (d) clouds are discarded if their thicknesses are less than $30.5 \mathrm{~m}$ for low clouds and $61 \mathrm{~m}$ for middle/high clouds.

\section{Comparing the cloud vertical structure derived from several methods \\ M. Costa-Surós et al.}

Title Page

Abstract Introduction

Conclusions

Tables References Figures

14

4

Back

Full Screen / Esc

Printer-friendly Version

\section{Close}




\subsection{Methodology}

First the radiosonde trajectory (only the vertical position is considered) is graphically superposed to the temporal evolution of ARSCL CBBE and the first three $\mathrm{CBH}$ and $\mathrm{CTH}$. From this representation, heights of cloud bases and tops are extracted by a vi-

5 sual inspection, obtaining what we call ARSCLv heights, which correspond to cloud bases and tops eventually crossed by the sonde during its ascent. These values will be the main reference considered in the present study for comparison. Additionally, the mean value of ARSCL cloud bases and tops is calculated, from the time when the RS is launched until half an hour later, will be denoted as ARSCLm. It has to be noted that 10 the CBBE (from VCEIL/MPL) is considered the first cloud base layer unless the first $\mathrm{CBH}$ (from MMCR/MPL) is lower.

Then, the next step is comparing the behavior of the six methods above described with ARSCL observations. First, the sky situations were classified into four categories (according to ARSCLv): "no clouds", "1 layer", "2 layers" or "more than 2 layers". Then, for every sky situation the methods were classified in several categories depending on the correspondence between the methods and the observations. Further, every case was labeled as false negative, false positive, perfect agreement, approximate agreement, or not coincident, defined as follows.

"False negative" means that no clouds were detected by the method when ARSCLV gives one or more cloud layers. "False positive" means that one or more cloud layers were detected by the method when ARSCLv does not give any cloud. "Perfect agreement" occurs when the method detects the same cloud layer/s (number and heights) as ARSCLv. "Approximate agreement" occurs when the method correctly detects at least one layer that ARSCLv gives, but disagrees on the whole cloud vertical structure. All

as the sum of the perfect agreement and the approximate agreement.

Regarding the matching between heights of cloud layers, the first step is to classify cloud layers (both from ARSCLv and the RS methods) as "low" (CBH<2000), "middle"

\section{Comparing the cloud vertical structure \\ derived from several methods \\ M. Costa-Surós et al.}

Title Page

Abstract Introduction

Conclusions

Tables References

Figures

14 $\Delta \mathbf{I}$

4

Back

Close 
(2000 m < CBH < $6000 \mathrm{~m})$ or "high" $(\mathrm{CBH}>6000 \mathrm{~m})$. For classifying the layers derived from the RS methods a tolerance interval of $\pm 300 \mathrm{~m}$ and $\pm 500 \mathrm{~m}$ is admitted when $\mathrm{CBH}$ is near a boundary ( $2000 \mathrm{~m}$ or $6000 \mathrm{~m}$ respectively). Secondly, a RS layer is considered as coincident to the ARSCLv layer if it belongs to the same class (low, 5 middle or high) and (i) the ARSCLv cloud layer and the RS cloud layer are partly or totally superimposed each other, or (ii) the $\mathrm{CBH}$ from the RS method does not differ for more than $150 \mathrm{~m}$ (low clouds), $300 \mathrm{~m}$ (middle clouds) or $600 \mathrm{~m}$ (high clouds) from the ARSCLv CBH.

\section{Results and discussion}

\subsection{Case studies}

We present here four analyzed cases that correspond to different sky situations (no clouds, low, middle, and high clouds respectively). Thus, Figs. 2 to 5 are composed by (a) the ARSCL and RS plots, (b) the cloud layers resulting from every applied method, and (c) some TSI images (only available for daytime situations). Specifically, panels

15 (a) of each Figs. 2-5 show the ARSCL products around the RS launch time, that is the Cloud Base Height Best Estimate (CBBE) and up to three bottom heights and top heights of hydrometeor layers from composite MMCR/MPL. In addition, the vertical position of the radiosounding depending on the time is shown on the same panel, so it is easy to see if the sonde crossed any cloud layer during its ascent. Panels (b) show, first of all, the cloud layers as detected by ARSCL (ARSCLm and ARSCLv), and second, the cloud layers found with the explained methods (PWR95, WR95, CE96, DS99, MNS05 and ZHA10). Figure 6 shows four GOES infrared images (one for each of the four cases studied) corresponding to approximately 25-40 min after the launch time. The SGP location and the position of the RS every $3 \mathrm{~km}$ height are indicated in these images.

\section{ACPD}

13, 14405-14445, 2013

Comparing the cloud vertical structure

derived from several methods

M. Costa-Surós et al.

Title Page

Abstract Introduction

Conclusions

References

Tables

Figures

14

$\Delta \mathbf{I}$

4

Back

Close

Full Screen / Esc

Printer-friendly Version

Interactive Discussion 
Figure 2a, corresponding to 15 April 2009, shows that during the RS ascent there were no clouds above the site (except for a tiny high cloud at around 11:40 UTC). This is supported by TSI images. Moreover, GOES images confirm that the RS moved through a region free of clouds (see Fig. 6a). Despite this, Fig. 1b shows that some methods 5 (CE96 and ZHA10) detect high clouds (producing a false positive); therefore these two methods find a moist layer, which could probably be related with clouds present earlier, or moisture at that level downstream of the ARSCL location that the RS passed through, and interpret it as a cloud. The other methods do not detect any cloud layers, as it should be according with ARSCL and satellite images (perfect agreement).

10 In Fig. 3a (15 October 2009) ARSCL data show that during the RS ascent there are two low, thin cloud layers below $1000 \mathrm{~m}$, although the higher layer disappeared at 05:30 UTC. Probably, the RS crossed these two layers, since the horizontal displacement during the few minutes that are needed by the RS to reach $1000 \mathrm{~m}$ is very small (see Fig. 6b). Despite of a relatively large maximum horizontal displacement, GOES images confirm that the RS moved through a region of homogeneous low clouds (Fig. 6b) so this profile is maintained in the dataset. Note that these low clouds, which have a temperature similar to surface, are hardly distinguishable in a static infrared image but become perceptible when the image sequence is inspected. Only CE96 method (Fig. $3 b$ ) detects these two layers, but it also finds other layers at middle and high levels of the troposphere that did not exist (therefore it is an approximate agreement). All other methods are also in approximate agreement with ARSCL because they detect the two layers as one layer.

For the case in Fig. 4a (10 July 2009), ARSCL observed a cloud layer at $5 \mathrm{~km}$ over SGP during the RS ascent, but PWR95 is the only method that detected it (Fig. 4b), showing a perfect agreement. The other methods are giving false negatives. Figure 4c shows that on the launch time (11:30 UTC) and also on the time when the RS reached $5 \mathrm{~km}(11: 48$ UTC) there are scattered clouds at SGP. GOES images show that the RS moved through a region with inhomogeneous mid-level cloudiness (Fig. 6c) so for this reason the profile is not included in the database. In fact, this case could be an example

\section{ACPD}

13, 14405-14445, 2013

Comparing the cloud vertical structure

derived from several methods

M. Costa-Surós et al.

Title Page
Abstract

Conclusions

Tables

14

4

Back
Introduction

References

Figures

$>1$

Close
Full Screen / Esc

Printer-friendly Version

Interactive Discussion 
of what Naud et al. (2003) already found: the disagreements between radar- (in our study ARSCL) and radiosonde-derived cloud boundaries may be caused by broken cloud situations when it is difficult to verify that fixed active sensors and radiosondes are observing the same clouds due to the horizontal drift of the latter.

$5 \quad$ For the case in Fig. 5 (20 January 2009) ARSCL detected a high cloud during the ascent of the RS. WR95, CE96 and ZHA10 methods detected the high cloud that ARSCL observed as well. However, PWR95, WR95 and CE96 also detected a low cloud layer between 760 to $810 \mathrm{~m}$, which in fact was observed by ARSCL quite latter (at 15:00 UTC, not shown). Again, CE96 method estimated some middle and high layers

10 that did not exist at the ARSCL location. Therefore, in this situation, there is an approximate agreement for WR95 and CE96, a perfect agreement for ZHA10, false negative for DS99 and MNS05, and a not coincident qualification for PWR95. The image from TSI (Fig. 5c) at 13:44 UTC (two hours after the RS launch) does not seem to show any cloud layer that the ARSCL data show at that time. Despite of the agreements of some 15 methods, this case is not included in the database because the GOES image (Fig. 6d) cannot confirm that high clouds were present neither over SGP nor over the region where the RS moved through.

\subsection{General results}

Table 4 summarizes the behavior of the six methods for cloud detection from radiosoundings when compared to ARSCL observations, for all the 125 profiles considered. The sky situations are classified into four categories using ARSCL data: "no clouds" (52 cases), "1 layer" (44), "2 layers" (22) or "more than 2 layers" (7). Then, for every sky situation the methods are classified in several categories depending on the coincidence with the number and position of observed layers. Further, every com25 parison is accounted as false negative, false positive, perfect agreement, approximate agreement, or not coincident as previously defined.

According with results in Table 4, the methods that behave better in general are PWR95, WR95, DS99 and ZHA10, with total agreements of around $85 \%$ and false

ACPD

$13,14405-14445,2013$

Comparing the cloud vertical structure derived from several methods

M. Costa-Surós et al.

Title Page

Abstract Introduction

Conclusions

Tables

References

Figures

14

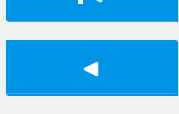

Back -1

$>$

Close

Full Screen / Esc

Printer-friendly Version

Interactive Discussion 
positive detections in less than $15 \%$ of cases. Two of these methods (PWR95 and ZHA10) stand out for their perfect agreement of $49 \%$. The poorest results are obtained by CE96 (total agreement, $44 \%$ ), which detects many layers that do not exist ( $22 \%$ of the times that CE96 detects clouds, they do not exist according with ARSCL, and $27 \%$ 5 of detected layers are not coincident with any ARSCL layer). Finally, MNS05 presents a very high ratio of perfect agreement $(62 \%)$ but it gives false negative detections very often (that is, the method does not detect clouds in $21 \%$ of cases), resulting in a total agreement of $78 \%$. If the analysis is done only with the cloudy situations (so without considering the "no clouds" cases) the four best methods improve their 10 total agreement up to values above $93 \%$ (not shown in Table 4). However, the perfect agreement worsens in all methods (an extreme case is CE96 method which decreases to $1 \%)$.

It is remarkable that the DS99 method is quite efficient despite its simplicity and the fact that it was developed mainly from stratiform situations. This method produces the 15 highest value of approximate agreements (46\%), due to a number of cases in which more layers than actually existent (according to ARSCL) are detected. For example, from the 44 one-layer cases, DS99 detects this layer correctly in 43 cases, and at least one more layer, in 35 of these. Similarly, from the 22 two-layer cases, DS99 detects both layers in 13 cases, but at least one more layer in 8 of them.

The major problem with MNS05 is that it tends to underestimate the presence of clouds in many situations (e.g., 15 out of 44 one-layer cases, 19 out of 22 two-layer cases, and 3 out of 7 more than two layer cases), for this reason its false negative percentage is so high globally $(21 \%)$ in comparison to the other methods. Accordingly, there are no false positive from MNS05, while all other methods have significantly higher values (from 10 to $22 \%$ ).

The method CE96 stands out for its false positive detections: the method produces more cloud layers than observed in 28 out of 52 no cloud cases, 32 out of 44 one-layer cases, 16 out of 22 two-layer cases; it seems that this method is too sensitive. Zhang et al. (2012) found the same behavior for CE96, and remarked that this method identi-

\section{ACPD}

13, 14405-14445, 2013

\section{Comparing the cloud vertical structure \\ derived from several methods \\ M. Costa-Surós et al.}

Title Page

Abstract

Introduction

Conclusions

References

Tables

Figures

14

-1

4

Back

Close

Full Screen / Esc

Printer-friendly Version

Interactive Discussion 
fies too many very thin cloud layers (our results indicate that CE96 detects high clouds $29 \%$ of the no clouds cases). In fact, Seidel and Durre (2003) had already criticized the use that Chernykh et al. (2001) made of CE96 method to analyze the trends in low and high cloud boundaries using radiosonde data obtained from 795 stations around 5 the world. Specifically, Seidel and Durre (2003) claimed that (1) the CE96 method is very sensitive to vertical resolution, and (2) the vertical resolution of soundings has increased over recent decades, and concluded that these limitations "undermined the credibility of the reported trends". Subsequently, Chernykh et al. (2003) replied to these criticisms arguing that the calculations in Chernykh et al. (2001) were accurate enough so the obtained trends represent atmospheric changes possibly due to climate change.

When the database is analyzed seasonally some interesting facts appear; the total agreement for each model and season is presented in Table 5. As can be seen in this table, the inter-seasonal variation of total agreement is very high for MNS05 (33\%), approximately double that for any other method indicating that this method has a distinct seasonal behavior. In summer, MNS05 loses many cloudiness situations while in winter it has a high perfect agreement. In contrast, PWR95 method is the most stable across the year. Regarding perfect agreement (not shown in Table 5), all methods show the maximum score in winter. This is due to the high number of "no clouds" situations in winter $(64 \%)$, which in general are correctly identified. The better performance of WR95, PWR95, DS99 and ZHA10 methods when the clear sky cases are not considered is quite stable across de year.

\subsection{ZHA10 tests and improvements}

As already commented, ZHA10 is an improvement of WR95, which in its turn is a modification of PWR95. In fact, the original reference of ZHA10 method (Zhang et al., 2010) presents a detailed comparison with cloud radar measurements that give the reference CVS, while the two earlier methods were compared against surface visual observations (and ISCCP data) which can hardly give an accurate description of the cloudiness structure. Our analyses produce similar results (for total and perfect agreements)

\section{ACPD}

13, 14405-14445, 2013

\section{Comparing the cloud vertical structure \\ derived from several methods \\ M. Costa-Surós et al.}

Title Page

Abstract Introduction

Conclusions

References

Tables

Figures

14

$\Delta \mathbf{I}$

4

Back

$>$

Close

Printer-friendly Version

Interactive Discussion 
regarding these three methods, nevertheless the perfect agreement for ZHA10 is better than PWR95 and WR95 when only cloudy situations are considered. In addition, a slight change in the ZHA10 method produces a noticeable improvement in its performance (see below). Therefore, we have chosen this method to try to make it suitable 5 for the low resolution vertical profiles that are used in atmospheric models. In parallel, we have checked the algorithm conditions for a moist layer to become a cloud layer and the conversion of relative humidity with respect to ice, besides the effect of coarsening of RS vertical resolution.

The original ZHA10 method gives a relatively high number of false positive detec10 tions, in particular for thin clouds. Therefore, in order to reduce this percentage we extended to the whole atmospheric profile the condition of the minimum thickness $(400 \mathrm{~m})$ of a moist layer to be considered as a cloud layer. Recall that ZHA10 applies this condition only to moist layers with bases lower than $120 \mathrm{~m}$. As expected, this new method, which will be denoted as ZHA10i, reduces false positive detections from $12 \%$ to $9 \%$ and improves the total agreement from $84 \%$ to $86 \%$. Remarkably, the perfect agreement rises from $49 \%$ to $58 \%$ (see Table 6). This later improvement is mainly linked to a better detection ("coincident") of one-layer cases (27 out of 44). These improvements spread along all seasons and also when only cloudy situations are considered.

Several studies (including methods ZHA10, WR95, MNS05, but also Yi et al., 2004, 20 for example) remark on the calculation of the relative humidity with respect to water or to ice when temperature is low enough. Therefore, we perform two tests: (1) removing the conversion of $\mathrm{RH}$ with respect to ice (ZHA10i-a); or (2) lowering the threshold temperature from $0{ }^{\circ} \mathrm{C}$ to $-20^{\circ} \mathrm{C}$ (ZHA10i-b). As can be seen in Table 6 , the overall behavior of these two tests is worse than ZHA10i. In fact, ZHA10i-a is less effective in general than ZHA10i: it loses more layers (especially high cloud layers) which increases the false negative detections (from $4 \%$ to $14 \%$ ) resulting in a total agreement reduction from $86 \%$ to $82 \%$. With ZHA10i-b, for the whole year neither the perfect agreement nor the approximate agreement changes with respect to ZHA10i. However, results of ZHA10i-b are seasonally dependent: agreements for winter and summer are

\section{ACPD}

$13,14405-14445,2013$

\section{Comparing the cloud vertical structure \\ derived from several methods \\ M. Costa-Surós et al.}

Title Page

Abstract Introduction

Conclusions

Tables

References

Figures

14

$\Delta \mathbf{I}$

4

Back

Close

Full Screen / Esc

Printer-friendly Version

Interactive Discussion 
similar than for ZHA10i, for spring are significantly better and for autumn, significantly worst. Therefore, further analyses and tests will be performed on ZHA10i, without any change regarding the treatment of relative humidity with respect to ice.

Weather forecast models (both global and mesoscale) and general circulation mod5 els used for climate assessment work have much coarser vertical resolution (i.e., a much lower number of levels) than the current vertical resolution of radiosoundings (see for example Table 2 in Crewell et al., 2004; or Table 1 in Illingworth et al., 2007). Specifically, the typical number of levels in the models is in the range of 30-60 (that is, resolution of around several hundred meters or several tenths of hectopascals), while 10 the typical number of levels in radiosoundings is of the order of several thousands (that is, as previously mentioned, resolution of few meters or about one hectopascal). Therefore, in order to check the applicability of the ZHA10i method to coarser resolution profiles simulating the vertical profiles given by a model, we downgraded the resolution of the radiosoundings using the procedure from Minnis et al. (2005) to decrease the vertical resolution to $25 \mathrm{hPa}$ (that is from around 3000 to 36 levels), and then applied the ZHA10i method.

Results of this test (ZHA10iLR hereinafter) show that the total agreement does not change in comparison to ZHA10i, but the perfect agreement is significantly higher (increasing from $58 \%$ to $63 \%)$. On the other hand, ZHA10iLR shows lower variability along the year, with the minimum total agreement in summer $(81 \%)$ and the maximum in spring $(90 \%)$. We also find that false negative situations increase (from $4 \%$ to $9 \%$ ), while false positive detections decrease (from $9 \%$ to $2 \%$ ). Therefore, the use of lower resolution (ZHA10iLR) does not imply poorer results; contrarily, in many situations the detection of cloud layers improves.

25 In fact, ZHA10iLR results were inspected in detail and we found that the method tends to produce less cloud layers (which can explain the transfer from false positive towards false negative detections), while the layers found tend to be thinner (which make them more similar to the ARSCL reference). There are three reasons for this behavior: first, some moist layers were not found because the interpolated (averaged)

\section{ACPD}

$13,14405-14445,2013$

\section{Comparing the cloud vertical structure \\ derived from several methods \\ M. Costa-Surós et al.}

Title Page

Abstract

Introduction

Conclusions

References

Tables

Figures

14

$>1$

4

Back

Close

Full Screen / Esc

Printer-friendly Version

Interactive Discussion 
$\mathrm{RH}$ values of the low resolution profile do not reach the min- $\mathrm{RH}$ threshold; second, some moist layers were not defined as cloud layers because the max- $\mathrm{RH}$ threshold that the method fixes within the layer is not reached. This is caused, in both cases, by the averaging of $\mathrm{RH}$ values involved when coarsening the resolution, which implies

5 a smoothing of the $\mathrm{RH}$ vertical profile. The third reason is that some moist layers were not considered as cloud layers because the thickness threshold $(>400 \mathrm{~m})$ is harder to accomplish in the low resolution profile.

To overcome these issues, we tried to improve the ZHA10iLR method. First we removed the condition on minimum cloud thickness ( $>400 \mathrm{~m}$ ) that we applied in ZHA10i.

10 This means that no restriction for cloud layer thickness is imposed; note, however, that the low resolution profile implies that even a single layer cloud has at least a thickness of $25 \mathrm{hPa}$ (i.e., $200 \mathrm{~m}$ at lower levels of the atmosphere or $1000 \mathrm{~m}$ at the higher levels). Second, the max-RH thresholds applied in ZHA10 original method were slightly reduced, to make the condition for a moist layer to become a cloud layer less restrictive.

15 The new values are given in Table 3. In fact, the effect of $\mathrm{RH}$ thresholds in the retrieval of CVS (in relation with different climates or different radiosonde instruments) has been discussed in previous studies (Wang et al., 1999; Naud et al., 2000; Zhang et al., 2012; among others). The test with these two changes is labeled as ZHA10LRnew in Table 6. The total agreement rises up to $91 \%$, and the perfect agreement is also quite good, $64 \%$. So it appears that, with these modifications, the method suggested by Zhang et al. (2010) has potential to be successfully applied to low resolution profiles as those provided by meteorological models. Note that these results are in fact slightly better than those obtained by ZHA10i on the high resolution profile. So we also tested the change of the max- $\mathrm{RH}$ threshold on this case, but the results (not shown) turned out to be somewhat worse. In summary, the original values of max-RH seem adequate for high resolution profiles, while the new thresholds suggested here appear more suitable for low resolution profiles.

\section{ACPD}

$13,14405-14445,2013$

\section{Comparing the cloud vertical structure \\ derived from several methods \\ M. Costa-Surós et al.}

Title Page

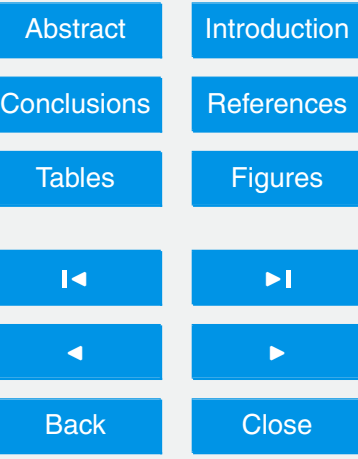

Full Screen / Esc

Printer-friendly Version 


\section{Conclusions}

Six methods to detect cloud layers from thermodynamic vertical atmospheric profiles have been applied to 125 radiosoundings from the SGP ARM site to find the cloud vertical structure; their performance has been assessed by comparison with ARSCL 5 data taken as a reference. Since large horizontal displacements can be achieved by the RS during their ascent, and to assure the homogeneity of the cloud field in the region, for a suitable comparison, GOES images have been used to endorse the RS database.

Four of the methods (PWR95, WR95, DS99, ZHA10) perform reasonably well, giv10 ing total agreements around $85 \%$, but differing among them in perfect agreement. Disagreements correspond to cases when (1) the instruments (ARSCL) classify cloud layers that some radiosounding methods fail to detect, and (2) some of these radiosounding methods are capable of detecting moist layers in the atmosphere that the instruments (ARSCL) do not classify as a cloud layer but that may be potential cloud air masses because of their high relative humidity (so they might be forming or dissipating clouds). This is not surprising in the case of subvisual clouds and given the lack of a refined physical definition, i.e., threshold, of what constitutes a cloud. In addition, despite of the selection of homogeneous cloudiness cases, a secondary explanation of disagreements may be the physical horizontal displacement of the sondes from the atmosphere directly above ARSCL, where the same moist layer might produce clouds or not in a horizontally dispersed pattern across the intervening area.

The ZHA10 method is the most recent version of the treatment initially proposed in PWR95 and WR95 and provides good enough results (total agreement of $84 \%$ and perfect agreement of $49 \%$ ) to be selected for further tests and improvements. Thus, 25 several tests were performed on this method by changing (1) the minimum thickness for a moist layer to be considered a cloud layer, (2) the threshold temperature to calculate $\mathrm{RH}$ with respect to water or with respect to ice, (3) the resolution of the atmospheric profile, and (4) the altitude dependent thresholds used to distinguish between moist
ACPD

$13,14405-14445,2013$

Comparing the cloud vertical structure

derived from several methods

M. Costa-Surós et al.

Title Page

Abstract Introduction

Conclusions

Tables References

Figures

14 -1

4

Back

Close 
and cloud layers. We found that removing the condition of a minimum thickness for a cloud results in an overall improvement of the method (total agreement, $86 \%$; perfect agreement, $58 \%$ ), but modifying the $\mathrm{RH}$ calculations does not produce any improvement.

5 A notable result of the present study comes from the tests performed with low resolution profiles. It appears that the method suggested by Zhang et al. (2010) has potential to be successfully applied to lower resolution profiles such as those used by meteorological and climate models. In fact, results with low resolution profiles and a new set of $\mathrm{RH}$ thresholds give slightly better overall results (total agreement $91 \%$, perfect agree10 ment $64 \%$ ) than those obtained by the original method, even when it is applied to high resolution profiles. This result could be valuable for improving cloud parameterizations in atmospheric models.

The present study extends previous comparison studies on RS methods used to obtain CVS, such as those by Naud et al. (2003) and Zhang et al. (2012), since it 15 considers more methods and accurately compares retrievals (layer by layer) against a reliable reference (ARSCL) and for an accurately selected set of cases. For example, Naud et al. (2003) found that WR95 and CE96 were generally consistent, but their analysis was limited to the lowest cloud bases and highest cloud tops. Obviously, it would be of interest to extend our analyses to other sites, larger datasets, or other references (such as those provided by satellite platforms, i.e. CloudSat and CALIPSO), but the improvement of the methods for deriving cloud vertical structure from radiosoundings (for example by including other variables such as vertical velocity) should be addressed as a priority.

Acknowledgements. This research was funded by the Ministerio de Ciencia e Innovación of 25 the Spanish Government through grants CGL2007-62664 (NUCLIEREX) and CGL2010-18546 (NUCLIERSOL) projects. Montse Costa-Surós was supported by research fellowship FPI BES2008-003129 from Ministerio de Ciencia e Innovación of the Spanish Government. Long acknowledges support from the Office of Science of the US Department of Energy as part of the Atmospheric Systems Research Program. Data were obtained from the Atmospheric Radiation 30 Measurement (ARM) Program sponsored by the US Department of Energy, US. We thank Lydia 14430

\section{ACPD}

13, 14405-14445, 2013

\section{Comparing the cloud vertical structure \\ derived from several methods \\ M. Costa-Surós et al.}

Title Page

Abstract

Introduction

Conclusions

References

Tables

Figures

14

DI

4

Back

$\checkmark$

Close

Printer-friendly Version

Interactive Discussion 
Dimitrieva-Arrago for her explanations and interesting discussions while visiting the University of Girona in the frame of the UE project CLIMSEAS (FP7-PEOPLE-2009-IRSES Proposal N. 247512). We also thank National Oceanic and Atmospheric Administration (NOAA) Comprehensive Large Array-data stewardship system (CLASS) to provide GOES images for research 5 use.

\section{References}

Chernykh, I., Alduchov, O., and Eskridge, R.: Trends in low and high cloud boundaries and errors in height determination of cloud boundaries, B. Am. Meteorol. Soc., 82, 1941-1947, 2001.

Chernykh, I. and Aldukhov, O.: Vertical distribution of cloud layers from atmospheric radiosounding data, Izv. Atmos. Ocean. Phy.+, 40, 41-53, 2004.

Chernykh, I. and Eskridge, R.: Determination of cloud amount and level from radiosonde soundings, J. Appl. Meteorol., 35, 1362-1369, 1996.

Chernykh, I., Alduchov, O., and Eskridge, R.: Comments on "Trends in low and high cloud boundaries and errors in height determination of cloud boundaries" - Reply, B. Am. Meteorol. Soc., 84, 241-247, doi:10.1175/BAMS-84-2-241, 2003.

Clothiaux, E., Ackerman, T., Mace, G., Moran, K., Marchand, R., and Miller, M.: Objective determination of cloud heights and radar reflectivities using a combination of active remote sensors at the ARM CART sites, J. Appl. Meteorol., 39, 645-665, 2000.

Crewell, S., Bloemink, H., Feijt, A., Garcia, S., Jolivet, D., and Krasnov, O.: The BALTEX bridge campaign - an integrated approach for a better understanding of clouds, B. Am. Meteorol. Soc., 85, 1565-1584, doi:10.1175/BAMS-85-10-1565, 2004.

Dimitrieva-Arrago, L. R. and Koloskova, L. F.: On approximate cloud boundary distribution method, (In Russian), Meteorol. Hydrol., N6, 47-52, 1969.

25 Dimitrieva-Arrago, L. R. and Shatunova, M. V.: The approximate method of the cloud boundaries definition and its vertical distribution restoration, Res. Act. Atmos. Ocean Model., 28, 4.5-4.6, 1999.

Eresmaa, N., Karppinen, A., Joffre, S. M., Räsänen, J., and Talvitie, H.: Mixing height determination by ceilometer, Atmos. Chem. Phys., 6, 1485-1493, doi:10.5194/acp-6-1485-2006, 2006.

\section{Comparing the cloud vertical structure \\ derived from several methods \\ M. Costa-Surós et al.}

Title Page

Abstract

Introduction

Conclusions

References

Tables

Figures

14

-1

4

Back

Close 
Han, D. and Ellingson, R.: An experimental technique for testing the validity of cumulus cloud parameterizations for longwave radiation calculations, J. Appl. Meteorol., 39, 1147-1159, 10.1175/1520-0450(2000)039<1147:AETFTT>2.0.CO;2, 2000.

Heintzenberg, J. and Charlson, R. J.: Clouds in the perturbed climate system: their relationship

5 to energy balance, atmospheric dynamics, and precipitation, The MIT Press, Cambridge, Massachusetts; London, 2009.

Illingworth, A., Hogan, R., O'Connor, E., Bouniol, D., Brooks, M., and Delanoe, J.: Cloudnet - continuous evaluation of cloud profiles in seven operational models using ground-based observations, B. Am. Meteorol. Soc., 88, 883-898, doi:10.1175/BAMS-88-6-883, 2007.

10 Jin, X., Hanesiak, J., and Barber, D.: Detecting cloud vertical structures from radiosondes and MODIS over Arctic first-year sea ice, Atmos. Res., 83, 64-76, 2007.

L'Ecuyer, T. and Jiang, J.: Touring the atmosphere aboard the A-Train, Phys. Today, 63, 36-41, 2010.

Minnis, P., Yi, Y. H., Huang, J. P., and Ayers, K.: Relationships between radiosonde and RUC-2 15 meteorological conditions and cloud occurrence determined from ARM data, J. Geophys. Res., 110, 1-19, 2005.

Morris, V.: Vaisala Ceilometer (VCEIL) Handbook, ARM Clim. Res. Facility, Richland, WA, USA, 2012.

Naud, C. M., Muller, J. P., and Clothiaux, E. E.: Comparison between active sensor and radiosonde cloud boundaries over the ARM Southern Great Plains site, J. Geophys. Res., 108, 1-12, 2003.

Nowak, D., Ruffieux, D., Agnew, J., and Vuilleumier, L.: Detection of fog and low cloud boundaries with ground-based remote sensing systems, J. Atmos. Ocean. Technol., 25, 13571368, 2008.

Poore, K., Wang, J., and Rossow, W.: Cloud layer thicknesses from a combination of surface and upper-air observations, J. Clim., 8, 550-568, 1995.

Qian, Y., Long, C. N., Wang, H., Comstock, J. M., McFarlane, S. A., and Xie, S.: Evaluation of cloud fraction and its radiative effect simulated by IPCC AR4 global models against ARM surface observations, Atmos. Chem. Phys., 12, 1785-1810, doi:10.5194/acp-12-1785-2012, $30 \quad 2012$.

Seidel, D. and Durre, I.: Comments on "Trends in low and high cloud boundaries and errors in height determination of cloud boundaries", B. Am. Meteorol. Soc., 84, 237-240, doi:10.1175/BAMS-84-2-237, 2003.
ACPD

13, 14405-14445, 2013

Comparing the cloud

vertical structure

derived from several methods

M. Costa-Surós et al.

Title Page

Abstract

Introduction

Conclusions

References

Tables

Figures

14

DI

4

Back

Close

Full Screen / Esc

Printer-friendly Version

Interactive Discussion 
Wang, J. and Rossow, W.: Determination of cloud vertical structure from upper-air observations, J. Appl. Meteorol., 34, 2243-2258, 1995.

Wang, J. and Rossow, W.: Effects of cloud vertical structure on atmospheric circulation in the GISS GCM, J. Clim., 11, 3010-3029, 1998.

5 Wang, J., Rossow, W., Uttal, T., and Rozendaal, M.: Variability of cloud vertical structure during ASTEX observed from a combination of rawinsonde, radar, ceilometer, and satellite, Mon. Weather Rev., 127, 2484-2502, 1999.

Wang, J., Rossow, W., and Zhang, Y.: Cloud vertical structure and its variations from a $20-\mathrm{yr}$ global rawinsonde dataset, J. Clim., 13, 3041-3056, 2000.

10 Xi, B., Dong, X., Minnis, P., and Khaiyer, M.: A 10 year climatology of cloud fraction and vertical distribution derived from both surface and GOES observations over the DOE ARM SPG site, J. Geophys. Res., 115, 1-12, doi:10.1029/2009JD012800, 2010.

Yi, Y. H., Minnis, P., Ayers, J. K., Huang, J. P., Doelling, D. R., Khaiyer, M. M., and Nordeen, M. L.: Relationships Between Meteorological Conditions and Cloud Properties Determined from ARM Data, 14th ARM Science Team Meeting Proceedings, Albuquerque, New Mexico, 22-26 March 2004, 1-18, 2004.

Zhang, J., Chen, H., Li, Z., Fan, X., and Peng, L.: Analysis of cloud layer structure in Shouxian, China using RS92 radiosonde aided by $95 \mathrm{GHz}$ cloud radar, J. Geophys. Res., 115, 1-13, 2010.

20 Zhang, J., Chen, H., Bian, J., Xuan, Y., and Duan, Y.: Development of cloud detection methods using CFH, GTS1, and RS80 radiosondes, Adv. Atmos. Sci., 29, 236-248, doi:10.1007/s00376-011-0215-4, 2012.

\section{ACPD}

$13,14405-14445,2013$

Comparing the cloud vertical structure

derived from several methods

M. Costa-Surós et al.

Title Page

Abstract

Introduction

Conclusions

References

Tables

Figures

14

$\rightarrow 1$

4

Back

Close

Full Screen / Esc

Printer-friendly Version

Interactive Discussion 
Table 1. Characteristics of instruments used as the basis of ARSCL value added product (extracted from the corresponding Handbooks from ARM Clim. Res. Facility).

\begin{tabular}{|c|c|c|c|}
\hline & $\begin{array}{l}\text { VCEIL } \\
\text { (Vaisala } \\
\text { Ceilometer CL31) }\end{array}$ & $\begin{array}{l}\text { MPL } \\
\text { (Micropulse } \\
\text { lidar) }\end{array}$ & $\begin{array}{l}\text { MMCR } \\
\text { (Millimeter } \\
\text { Cloud Radar) }\end{array}$ \\
\hline Vertical range & $7700 \mathrm{~m}$ & Up to $20 \mathrm{~km}$ & Up to $20 \mathrm{~km}$ \\
\hline Maximum range for cloud base height & $7500 \mathrm{~m}$ & $18 \mathrm{~km}$ & \\
\hline Resolution & $10 \mathrm{~m}$ & $15 \mathrm{~m}$ & \\
\hline Wavelength & $910 \mathrm{~nm}\left(\right.$ at $\left.25^{\circ} \mathrm{C}\right)$ & $532 \mathrm{~nm}$ & $\begin{array}{l}8.66 \mathrm{~mm}, \mathrm{Ka}-\text { band } \\
\text { (Frequency } 34.86 \mathrm{GHz} \text { ) }\end{array}$ \\
\hline Accuracy/uncertainty & $\pm 1 \%$ or $\pm 5 \mathrm{~m}$ & $\pm 2 \%$ & \\
\hline Minimum detection height & $0 \mathrm{~m}$ & $150 \mathrm{~m}$ & \\
\hline
\end{tabular}

Comparing the cloud vertical structure derived from several methods

M. Costa-Surós et al.

Title Page

Abstract

Introduction

Conclusions

References

Tables

Figures

14

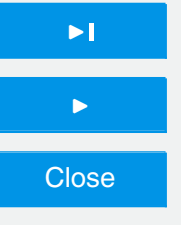

Back

Full Screen / Esc

Printer-friendly Version

Interactive Discussion 


\section{ACPD}

$13,14405-14445,2013$

Table 2. Summary of the applied RS methods.

\begin{tabular}{|c|c|c|c|c|c|c|c|c|}
\hline Acronym & References & $\begin{array}{l}\text { Cloud base and top height } \\
\text { estimation methodology }\end{array}$ & $\begin{array}{l}\text { Resolution } \\
\text { (approx. } \\
\text { number of } \\
\text { levels) }\end{array}$ & Max. height & Data used & $\mathrm{RH}_{\text {ice }}$ & $\begin{array}{l}\text { Min. thick- } \\
\text { nesses }(m)\end{array}$ & $\begin{array}{l}\text { Min. } \\
\text { CBH } \\
(\mathrm{m})\end{array}$ \\
\hline PRW95 & $\begin{array}{l}\text { Poore, Wang and } \\
\text { Rossow (1995) }\end{array}$ & $\begin{array}{l}\text { Temperature-dependent } \\
\text { dew point depression } \\
\text { thresholds }\end{array}$ & $76 \mathrm{~m}(140)$ & $\begin{array}{l}\text { Tropopause } \\
\text { or } 10668 \mathrm{~m}\end{array}$ & $\begin{array}{l}z, \quad T_{\text {dry }} \text { and } \\
T_{\text {dew }}\end{array}$ & No & $\begin{array}{l}30.5 \text { (low) } 61 \\
\text { (middle, high) }\end{array}$ & No \\
\hline WR95 & $\begin{array}{l}\text { Wang and } \\
\text { Rossow (1995) }\end{array}$ & $\begin{array}{l}\text { Two RH thresholds } \\
(\operatorname{minRH}=84 \% \text { and } \\
\operatorname{maxRH}=87 \%) \text { and } 3 \% \\
\text { jump. }\end{array}$ & $\operatorname{Low}^{\mathrm{a}}(180)$ & $10 \mathrm{hPa}$ & $\begin{array}{l}z, T_{\text {dry }}, P \text { and } \\
\mathrm{RH}\end{array}$ & If $T<0^{\circ} \mathrm{C}$ & No & 500 \\
\hline CE96 & $\begin{array}{l}\text { Chernykh and Eskridge (1996), } \\
\text { and Chernykh and Aldukhov (2004) }\end{array}$ & $\begin{array}{l}\text { Sign of the second-order } \\
\text { derivatives with respect to } \\
\text { height of the } T \text { and } \mathrm{RH} \\
\left(T^{\prime \prime}(z) \geq 0 \text { and } R^{\prime \prime}(z) \leq 0\right)\end{array}$ & $\operatorname{Low}^{\mathrm{a}}(180)$ & $10 \mathrm{hPa}$ & $\begin{array}{l}z, \quad P, \quad T_{\mathrm{dry}} \\
T_{\mathrm{dew}} \text { and RH }\end{array}$ & If $T<0^{\circ} \mathrm{C}$ & 100 & 0 \\
\hline DS99 & $\begin{array}{l}\text { Dimitrieva-Arrago and } \\
\text { Shatunova (1999) }\end{array}$ & $\begin{array}{l}\text { Pressure-dependent dew } \\
\text { point depression thresh- } \\
\text { olds }\end{array}$ & $\begin{array}{l}\operatorname{High}^{\mathrm{b}} \\
(3000)\end{array}$ & $300 \mathrm{hPa}$ & $\begin{array}{l}z, P, T_{\mathrm{dry}} \text { and } \\
T_{\mathrm{dew}}\end{array}$ & No & No & 0 \\
\hline MNS05 & Minnis et al. (2005) & $\begin{array}{l}\text { Empirical parameterization } \\
\text { calculating the probability } \\
\text { of occurrence (Pcld) of } \\
\text { a cloud layer using RH and } \\
T \text { [Pcld }(T, \mathrm{RH})>67 \%]\end{array}$ & $\begin{array}{l}25 \mathrm{hPa} \\
(36)\end{array}$ & $100 \mathrm{hPa}$ & $\begin{array}{l}z, P, T_{\text {dry }} \text { and } \\
\mathrm{RH}\end{array}$ & If $T<-20^{\circ} \mathrm{C}$ & No & 0 \\
\hline ZHA10 & Zhang et al. (2010) & $\begin{array}{l}\text { Improvement of the WR95 } \\
\text { method (altitude depen- } \\
\text { dent minRH and maxRH } \\
\text { thresholds, without the } 3 \% \\
\text { jump) }\end{array}$ & $\begin{array}{l}\mathrm{High}^{\mathrm{b}} \\
(3000)\end{array}$ & $\begin{array}{l}\text { Top of the } \\
\text { profile }\end{array}$ & $\begin{array}{l}z, \quad T_{\text {dry }} \text { and } \\
\mathrm{RH}\end{array}$ & If $T<0^{\circ} \mathrm{C}$ & $\begin{array}{l}30.5 \text { (low) } 61 \\
\text { (middle, high) }\end{array}$ & 280 \\
\hline
\end{tabular}

${ }^{\mathrm{a}} \mathrm{A}$ low resolution $\mathrm{RS}$ is built from the original RS (see text for details).

${ }^{\mathrm{b}}$ High resolution means all available data in the RS (without any transformation).

Comparing the cloud vertical structure derived from several methods

\section{Costa-Surós et al.}

\section{Title Page}

Abstract

Introduction

Conclusions

References

Tables

Figures

14

$>1$

Back

\section{Full Screen / Esc}

Printer-friendly Version

Interactive Discussion 
Comparing the cloud vertical structure derived from several methods

M. Costa-Surós et al.

Table 3. Summary of the values for min- $\mathrm{RH}$, inter- $\mathrm{RH}$ and max- $\mathrm{RH}$, from Zhang et al. (2010) and the new max- $\mathrm{RH}$ thresholds suggested for the low resolution test.

\begin{tabular}{lllll}
\hline Altitude Range & ZHA10 min-RH & ZHA10 inter-RH & ZHA10 max-RH & New max-RH \\
\hline $0-2 \mathrm{~km}$ & $92-90 \%$ & $84-82 \%$ & $95-93 \%$ & $93.5-91.5 \%$ \\
$2-6 \mathrm{~km}$ & $90-88 \%$ & $82-78 \%$ & $93-90 \%$ & $91.5-89 \%$ \\
$6-12 \mathrm{~km}$ & $88-75 \%$ & $78-70 \%$ & $90-80 \%$ & $89-77.5 \%$ \\
$>12 \mathrm{~km}$ & $75 \%$ & $70 \%$ & $80 \%$ & $77.5 \%$ \\
\hline
\end{tabular}

Title Page

Abstract

Introduction

Conclusions

References

Tables

Figures

14

$>1$

4

Back

Close

Full Screen / Esc

Printer-friendly Version

Interactive Discussion 
Table 4. Behavior of the six RS methods for cloud detection compared to ARSCL observations.

\begin{tabular}{|c|c|c|c|c|c|c|c|c|c|c|}
\hline \multicolumn{3}{|c|}{ ARSCL (Visu) } & \multirow{2}{*}{\multicolumn{2}{|c|}{ Situation }} & \multicolumn{6}{|c|}{ METHOD (number of cases) } \\
\hline & & & & & \multirow[t]{2}{*}{ PWR95 } & \multirow[t]{2}{*}{ WR95 } & \multirow[t]{2}{*}{ CE96 } & \multirow[t]{2}{*}{ DS99 } & \multirow[t]{2}{*}{ MNS05 } & \multirow[t]{2}{*}{ ZHA10 } \\
\hline Situation & Num. Cases & $\%$ & & & & & & & & \\
\hline \multirow{4}{*}{ No clouds } & \multirow{4}{*}{52} & \multirow{4}{*}{41.6} & \multicolumn{2}{|l|}{ No clouds } & 40 & 35 & 24 & 37 & 52 & 37 \\
\hline & & & Clouds (1st $\mathrm{CBH}$ ) & Low & 6 & 7 & 7 & 8 & 0 & 4 \\
\hline & & & & Middle & 6 & 6 & 6 & 6 & 0 & 4 \\
\hline & & & & High & 0 & 4 & 15 & 1 & 0 & 7 \\
\hline \multirow{5}{*}{1 layer } & \multirow{5}{*}{44} & \multirow{5}{*}{35.2} & \multicolumn{2}{|l|}{ No clouds } & 0 & 0 & 4 & 0 & 15 & 1 \\
\hline & & & \multirow[t]{2}{*}{1 layer } & Coincident & 18 & 13 & 1 & 8 & 22 & 21 \\
\hline & & & & Not coincident & 2 & 0 & 7 & 1 & 0 & 2 \\
\hline & & & \multirow[t]{2}{*}{$>1$ layer } & Some is coincident & 24 & 30 & 10 & 35 & 6 & 20 \\
\hline & & & & Any coincidence & 0 & 1 & 22 & 0 & 1 & 0 \\
\hline \multirow{9}{*}{2 layers } & \multirow{9}{*}{22} & \multirow{9}{*}{17.6} & \multicolumn{2}{|l|}{ No clouds } & 0 & 0 & 2 & 0 & 8 & 0 \\
\hline & & & \multirow[t]{2}{*}{1 layer } & One is coincident & 4 & 7 & 0 & 3 & 10 & 8 \\
\hline & & & & No coincidence & 0 & 0 & 1 & 0 & 1 & 0 \\
\hline & & & \multirow[t]{3}{*}{2 layers } & Coincident & 3 & 4 & 0 & 5 & 3 & 3 \\
\hline & & & & One is coincident & 5 & 1 & 2 & 0 & 0 & 3 \\
\hline & & & & Any coincidence & 0 & 0 & 1 & 0 & 0 & 1 \\
\hline & & & \multirow[t]{3}{*}{$>2$ layers } & One is coincident & 3 & 2 & 8 & 6 & 0 & 5 \\
\hline & & & & 2 coincident & 7 & 8 & 5 & 8 & 0 & 2 \\
\hline & & & & Any coincidence & 0 & 0 & 3 & 0 & 0 & 0 \\
\hline \multirow{10}{*}{$>2$ layers } & \multirow{10}{*}{7} & & No clouds & & 1 & 0 & 2 & 0 & 3 & 1 \\
\hline & & & Perfect agreemer & & 0 & 0 & 0 & 0 & 0 & 0 \\
\hline & & 5.6 & Aproximate agree & nent & 6 & 7 & 5 & 6 & 4 & 6 \\
\hline & & & Any coincidence & & 0 & 0 & 0 & 1 & 0 & 0 \\
\hline & & & False negative & & $1 \%$ & $0 \%$ & $6 \%$ & $0 \%$ & $21 \%$ & $2 \%$ \\
\hline & & & False positive & & $10 \%$ & $14 \%$ & $22 \%$ & $12 \%$ & $0 \%$ & $12 \%$ \\
\hline & & & Not coincident & & $2 \%$ & $1 \%$ & $27 \%$ & $2 \%$ & $2 \%$ & $2 \%$ \\
\hline & & & Perfect agreemer & & $49 \%$ & $42 \%$ & $20 \%$ & $40 \%$ & $62 \%$ & $49 \%$ \\
\hline & & & Aproximate agree & nent & $39 \%$ & $44 \%$ & $24 \%$ & $46 \%$ & $16 \%$ & $35 \%$ \\
\hline & & & Total agreement & & $88 \%$ & $86 \%$ & $44 \%$ & $86 \%$ & $78 \%$ & $84 \%$ \\
\hline
\end{tabular}

Comparing the cloud vertical structure

derived from several methods

M. Costa-Surós et al.

\section{Title Page}

\section{Abstract}

Introduction

Conclusions

References

Tables

Figures

14

DI

4

Back

Full Screen / Esc

Printer-friendly Version

Interactive Discussion 
Table 5. Seasonal values of total agreement and its maximum difference for each method (W: winter, Sp: Spring, Su: Summer and A: autumn).

\begin{tabular}{lllllc}
\hline Method & \multicolumn{3}{c}{ Total agreement (\%) } & $\begin{array}{c}\text { Max. } \\
\text { Variation (\%) }\end{array}$ \\
\cline { 2 - 4 } & W & Sp & Su & A & \\
\hline PWR95 & 91 & 86 & 92 & 84 & 8 \\
WR95 & 79 & 90 & 96 & 81 & 17 \\
CE96 & 45 & 45 & 35 & 49 & 14 \\
DS99 & 91 & 86 & 88 & 81 & 10 \\
MNS05 & 91 & 76 & 58 & 81 & 33 \\
ZHA10 & 88 & 79 & 92 & 78 & 14 \\
\hline
\end{tabular}

ACPD

13, 14405-14445, 2013

Comparing the cloud vertical structure

derived from several methods

M. Costa-Surós et al.

Title Page

Abstract

Introduction

Conclusions

References

Tables

Figures

14

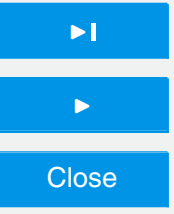

Back

Full Screen / Esc

Printer-friendly Version

Interactive Discussion 
Table 6. Behavior of the tests performed on ZHA10 method compared to ARSCL observations.

\begin{tabular}{|c|c|c|c|c|c|c|c|c|c|c|}
\hline \multicolumn{3}{|c|}{ ARSCL (Visu) } & \multicolumn{2}{|l|}{ Situation } & \multicolumn{6}{|c|}{ METHOD (number of cases) } \\
\hline & & & & & \multirow[t]{2}{*}{ ZHA10 } & \multirow[t]{2}{*}{ ZHA10i } & \multirow[t]{2}{*}{ ZHA10i-a } & \multirow[t]{2}{*}{ ZHA10i-b } & \multirow[t]{2}{*}{ ZHA10iLR } & \multirow[t]{2}{*}{ ZHA10LRnew } \\
\hline Situation & Num. Cases & $\%$ & & & & & & & & \\
\hline \multirow{4}{*}{ No clouds } & \multirow{4}{*}{52} & \multirow{4}{*}{$42 \%$} & \multicolumn{2}{|l|}{ No clouds } & 37 & 41 & 49 & 41 & 50 & 49 \\
\hline & & & \multirow[t]{3}{*}{ Clouds (1st CBH) } & Low & 4 & 2 & 2 & 3 & 1 & 2 \\
\hline & & & & Middle & 4 & 4 & 1 & 2 & 0 & 0 \\
\hline & & & & High & 7 & 5 & 0 & 6 & 1 & 1 \\
\hline \multirow{5}{*}{1 layer } & \multirow{5}{*}{44} & \multirow{5}{*}{$35 \%$} & \multicolumn{2}{|l|}{ No clouds } & 1 & 4 & 11 & 4 & 9 & 5 \\
\hline & & & \multirow[t]{2}{*}{1 layer } & Coincident & 21 & 27 & 25 & 27 & 27 & 28 \\
\hline & & & & Not coincident & 2 & 0 & 0 & 1 & 3 & 0 \\
\hline & & & \multirow[t]{2}{*}{$>$ 1layer } & Some is coincident & 20 & 13 & 8 & 12 & 5 & 11 \\
\hline & & & & Any coincidence & 0 & 0 & 0 & 0 & 0 & 0 \\
\hline \multirow{9}{*}{2 layers } & \multirow{9}{*}{22} & \multirow{9}{*}{$18 \%$} & \multicolumn{2}{|l|}{ No clouds } & 0 & 0 & 4 & 0 & 1 & 1 \\
\hline & & & \multirow[t]{2}{*}{1 layer } & One is coincident & 8 & 10 & 12 & 11 & 14 & 13 \\
\hline & & & & No coincidence & 0 & 0 & 1 & 0 & 0 & 0 \\
\hline & & & \multirow[t]{3}{*}{2 layers } & Coincident & 3 & 4 & 2 & 3 & 2 & 3 \\
\hline & & & & One is coincident & 3 & 2 & 1 & 2 & 4 & 3 \\
\hline & & & & Any coincidence & 1 & 2 & 0 & 2 & 0 & 1 \\
\hline & & & \multirow[t]{3}{*}{$>$ 2layers } & One is coincident & 5 & 2 & 1 & 2 & 0 & 0 \\
\hline & & & & 2 coincident & 2 & 2 & 1 & 2 & 1 & 1 \\
\hline & & & & Any coincidence & 0 & 0 & 0 & 0 & 0 & 0 \\
\hline \multirow{10}{*}{$>2$ layers } & & & No clouds & & 1 & 1 & 3 & 1 & 1 & 1 \\
\hline & & & Perfect agreemen & & 0 & 0 & 0 & 0 & 0 & 0 \\
\hline & 7 & $6 \%$ & Aproximate agreer & nent & 6 & 6 & 4 & 6 & 6 & 6 \\
\hline & & & Any coincidence & & 0 & 0 & 0 & 0 & 0 & 0 \\
\hline & & & False negative & & $2 \%$ & $4 \%$ & $14 \%$ & $4 \%$ & $9 \%$ & $6 \%$ \\
\hline & & & False positive & & $12 \%$ & $9 \%$ & $2 \%$ & $9 \%$ & $2 \%$ & $2 \%$ \\
\hline & & & Not coincident & & $2 \%$ & $2 \%$ & $1 \%$ & $2 \%$ & $2 \%$ & $1 \%$ \\
\hline & & & Perfect agreemen & & $49 \%$ & $58 \%$ & $61 \%$ & $57 \%$ & $63 \%$ & $64 \%$ \\
\hline & & & Aproximate agreer & nent & $35 \%$ & $28 \%$ & $22 \%$ & $28 \%$ & $24 \%$ & $27 \%$ \\
\hline & & & Total agreement & & $84 \%$ & $86 \%$ & $82 \%$ & $85 \%$ & $87 \%$ & $91 \%$ \\
\hline
\end{tabular}

ACPD

13, 14405-14445, 2013

Comparing the cloud vertical structure

derived from several methods

M. Costa-Surós et al.

Title Page

Abstract

Introduction

Conclusions

References

Tables

Figures

14

DI

4

Back

Close

Full Screen / Esc

Printer-friendly Version

Interactive Discussion 


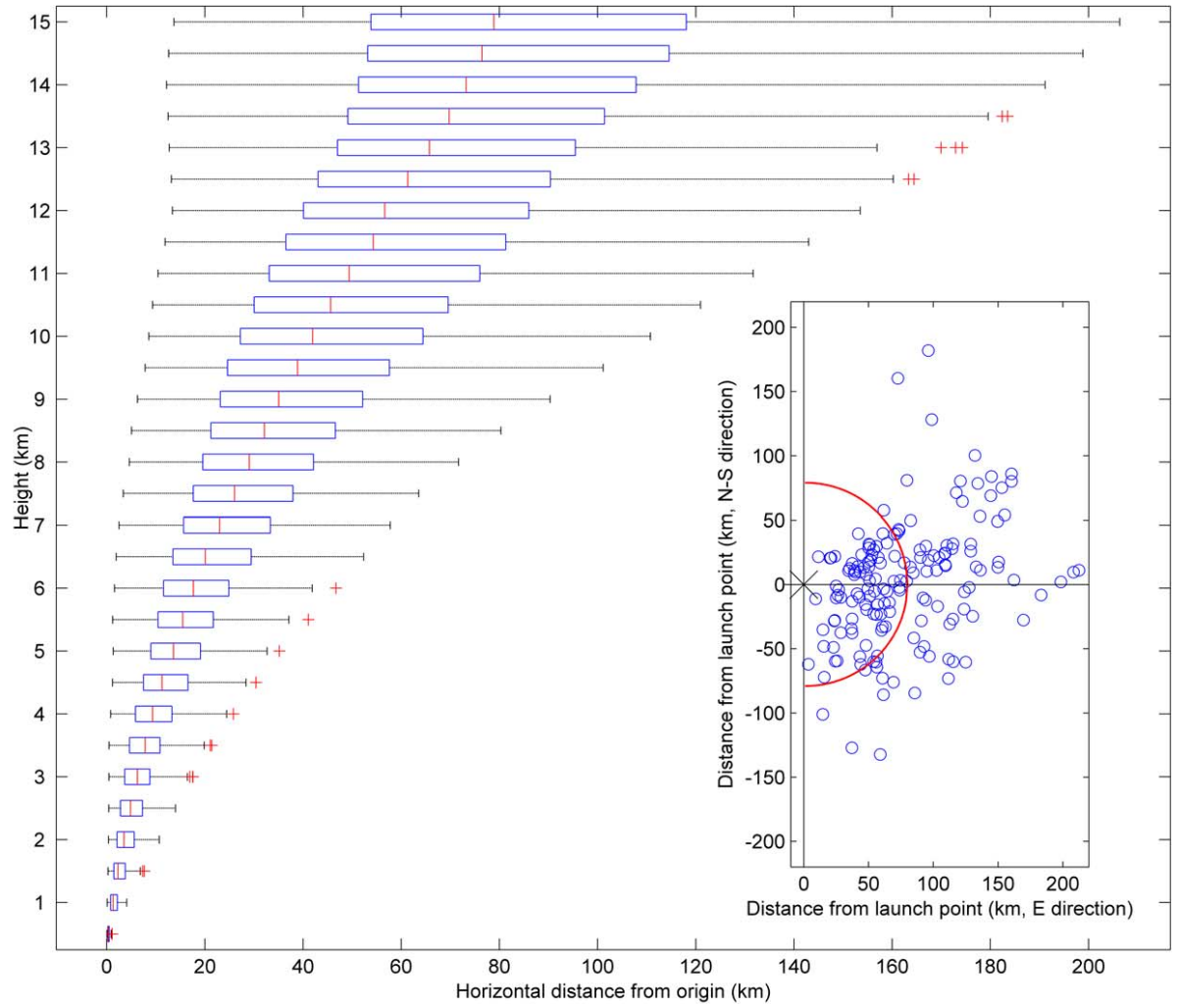

Fig. 1. The boxplot shows the horizontal displacement, every $500 \mathrm{~m}$ height, of the $165 \mathrm{ra}-$ diosondes launched from SGP (the boxplot shows the minimum, the first quartile, the median, the third quartile, the maximum and, if any, observations that might be considered outliers (plus symbols)). The inset shows the horizontal projection vision of the RS position with respect to the launch point when they reach $15 \mathrm{~km}$. The semi-circle represents the median of all displacements $(79 \mathrm{~km})$.

\section{ACPD}

13, 14405-14445, 2013

Comparing the cloud vertical structure derived from several methods

M. Costa-Surós et al.

Title Page

Abstract

Introduction

Conclusions

References

Tables

Figures

14

$\Delta$

4

Back

Close

Full Screen / Esc

Printer-friendly Version

Interactive Discussion 


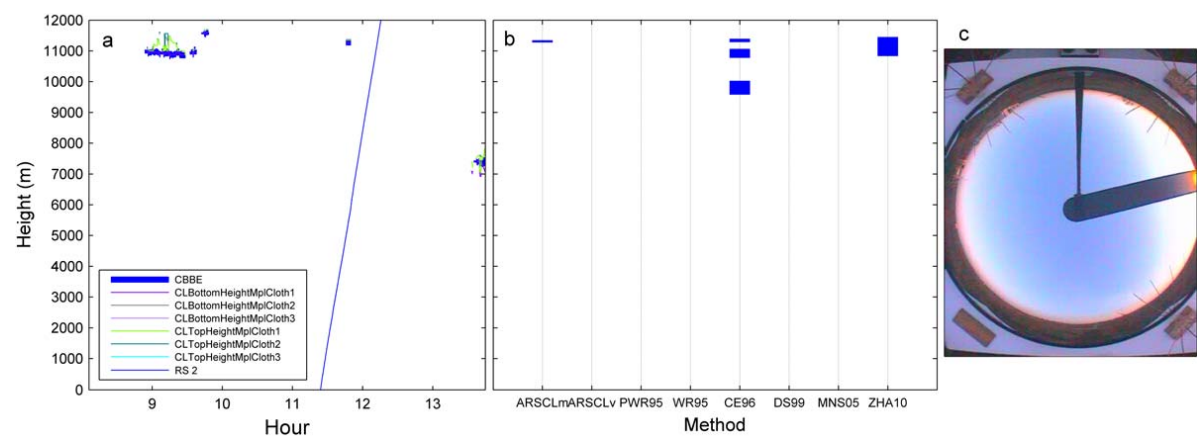

Fig. 2. Case 1: 15 April 2009, no clouds. (a) Vertical position of the radiosounding depending on the time and the ARSCL products around the RS launch time (11:21 UTC). (b) Cloud layers as detected by ARSCL (ARSCLm and ARSCLV), and as found by the explained methods (PWR95, WR95, CE96, DS99, MNS05 and ZHA10). (c) TSI image at 12:00 UTC (no earlier images available).

\section{ACPD}

13, 14405-14445, 2013

Comparing the cloud vertical structure

derived from several methods

M. Costa-Surós et al.

\section{Title Page}

\section{Abstract}

Introduction

Conclusions

References

Tables

Figures

14

$\Delta$

Back

Close

\section{Full Screen / Esc}

Printer-friendly Version

Interactive Discussion 

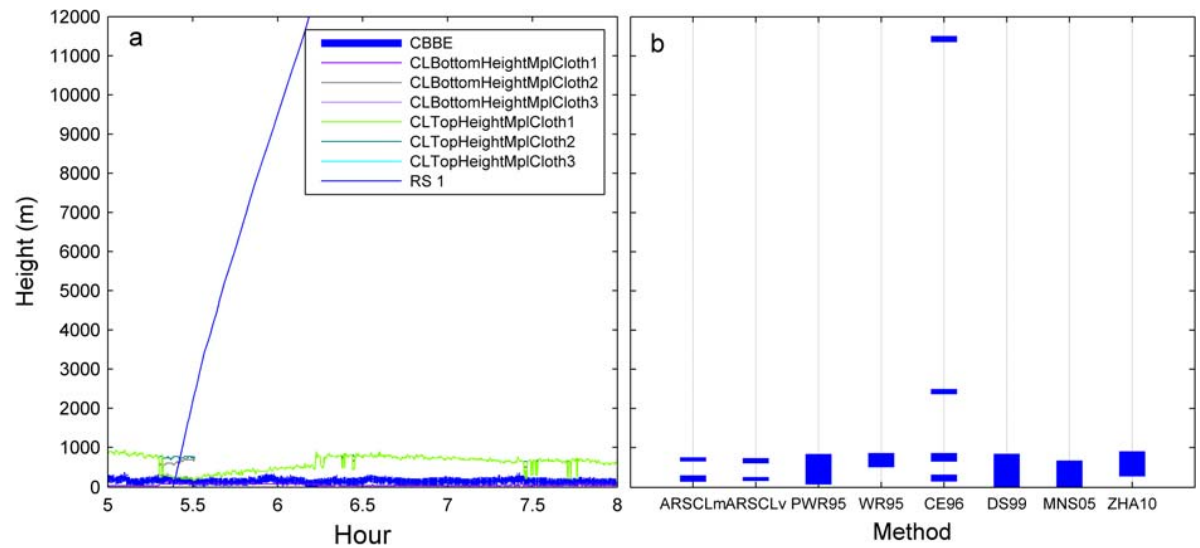

Fig. 3. Idem as Fig. 1, but for Case 2: 15 October 2009, Low clouds. RS launch time: 05:23 UTC.

\section{ACPD}

13, 14405-14445, 2013

Comparing the cloud vertical structure

derived from several methods

M. Costa-Surós et al.

\section{Title Page}

Abstract

Conclusions

Tables

14

Back

\section{Full Screen / Esc}

Printer-friendly Version

Interactive Discussion 


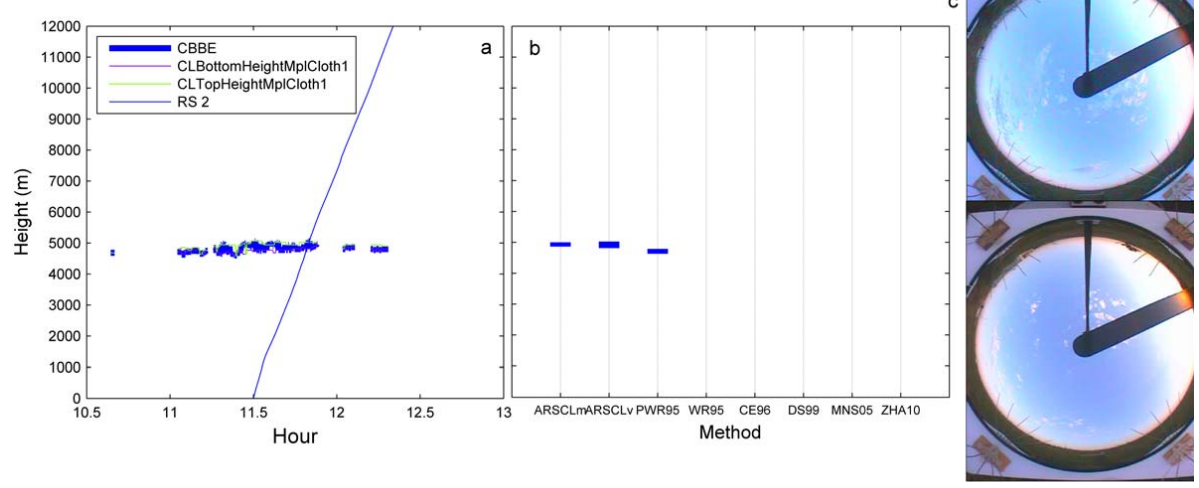

Fig. 4. Idem as Fig. 1, but for Case 3: 10 July 2009, Middle clouds. RS launch time: 11:30 UTC. TSI images at 11:30 and 11:48 UTC.

\section{ACPD}

13, 14405-14445, 2013

Comparing the cloud vertical structure

derived from several methods

M. Costa-Surós et al.

\section{Title Page}

Abstract

Conclusions

\section{Tables}

14

4

Back

\section{Full Screen / Esc}

Printer-friendly Version 


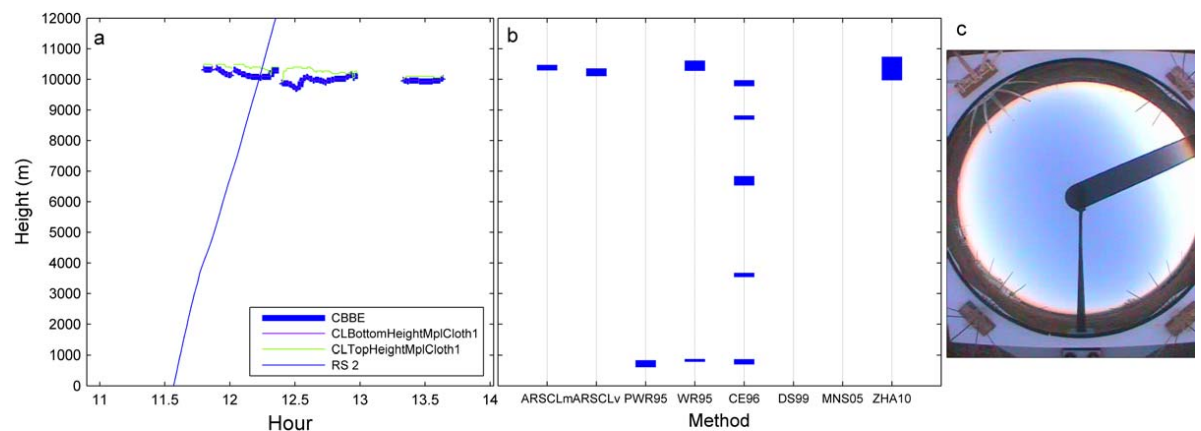

Fig. 5. Idem as Fig. 1, but for Case 4: 20 January 2009, High clouds. RS launch time: 11:34 UTC. TSI image at 13:44 UTC.

\section{ACPD}

13, 14405-14445, 2013

Comparing the cloud vertical structure

derived from several methods

M. Costa-Surós et al.

\section{Title Page}

Abstract

Introduction

Conclusions

References

Tables

Figures

14

I

4

Back

\section{Close}

\section{Full Screen / Esc}

Printer-friendly Version

Interactive Discussion 

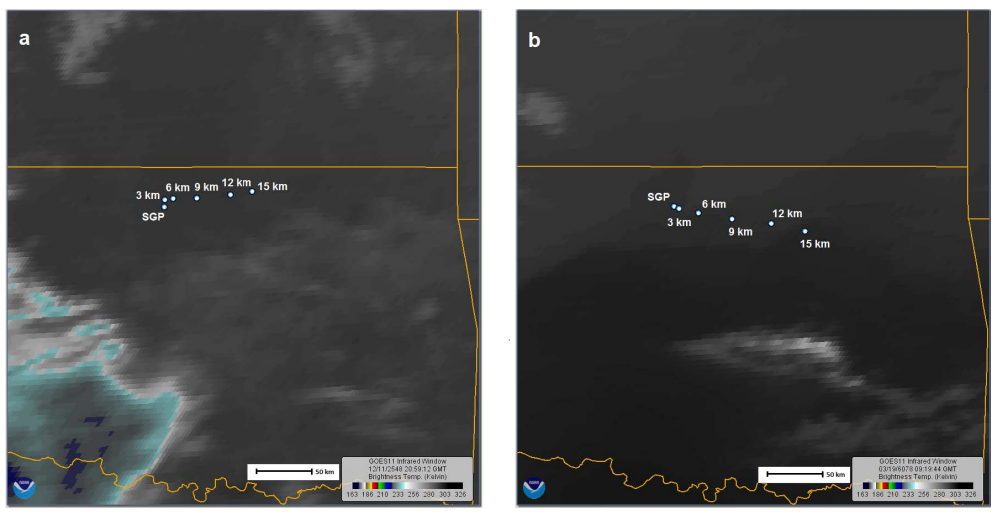

\section{ACPD}

13, 14405-14445, 2013

Comparing the cloud vertical structure

derived from several methods

M. Costa-Surós et al.
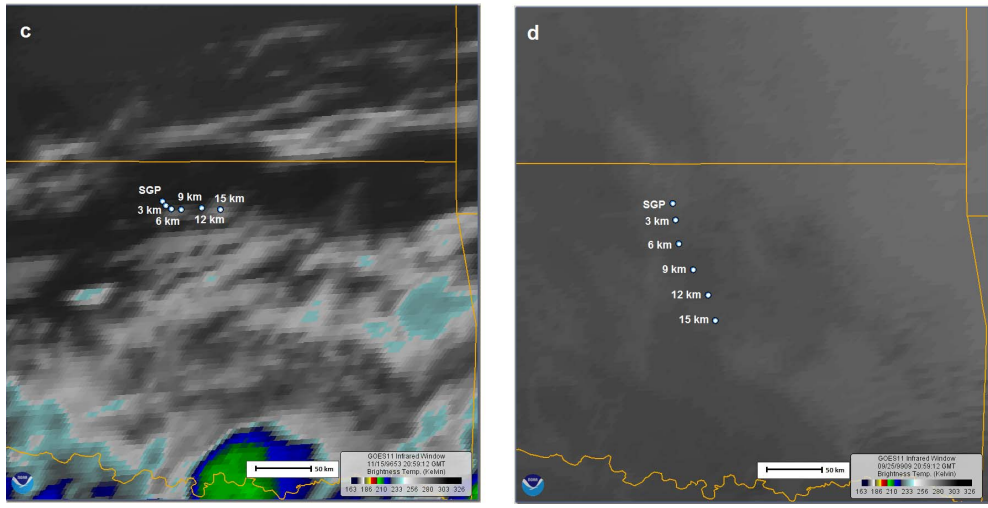

Title Page

Abstract

Conclusions

Tables

14

4

Back

\section{Close}

Fig. 6. GOES images in the infrared channel for the four cases studied approximately $25-40 \mathrm{~min}$ from the launch time: (a) 15 April 2009 at 12:00 UTC, (b) 15 October 2009 at 06:00 UTC, (c) 5 July 2009 at 12:00 UTC and (d) 20 January 2009 at 12:00 UTC. Dots indicate the horizontal position of the RS every $3 \mathrm{~km}$ height.

Printer-friendly Version

Interactive Discussion 